\title{
Nowe aspekty modyfikacji spektralnej pola sejsmicznego fal podłużnych z wykorzystaniem pomiarów prędkości fal poprzecznych w otworze
}

\begin{abstract}
W artykule przedstawiono koncepcję wykorzystania pomiarów prędkości fal poprzecznych w otworze do określenia krzywej refleksyjności fali skręceniowej S, dla estymacji operatorów modyfikacji spektralnej pola sejsmicznych fal podłużnych P. Zaproponowaną nowatorską metodykę przetestowano na materiale modelowym (modele teoretyczne) oraz na rzeczywistych danych polowych z obszaru północno-wschodniej Polski.
\end{abstract}

Słowa kluczowe: fala kompresyjna, fala skręceniowa, rozdzielczość rejestracji sejsmicznych, charakterystyka spektralna, sygnał elementarny, modelowanie sejsmiczne, sejsmogramy teoretyczne, krzywa refleksyjności.

\section{New aspects of spectral modification of compressional seismic waves field with the applicaton of shear wave borehole data}

In the paper a new idea of application of shear waves velocity received from borehole measurements, are presented. Reflectivity function recovered from the above data, are used for the estimation of an operator of the spectral modification of compressional (longitudinal) seismic waves. The proposed methodology was tested on model material (theoretical models) and on field data from North-East Poland.

Keys words: compressional and shear waves, resolution of seismic data, reflectivity function, spectral characteristics, seismic modeling, seismic wavelet.

\section{Wprowadzenie}

Pozytywne efekty praktycznego wykorzystania modyfikacji spektralnej pola falowego w celu zwiększenia rozdzielczości interpretacji geologicznej obiektów złożowych, wynikające z zastosowania operatorów obliczanych na podstawie pomiarów otworowych fali podłużnej P $[6-8,10]$, zainspirowały do zbadania i przeanalizowania możliwości użycia pełnego pola falowego rejestrowanego w otworze (fale sprężyste podłużne i poprzeczne) do modyfikacji charakterystyki spektralnej sekcji sejsmicznej fal podłużnych rejestrowanych powierzchniowo. Eksperyment taki okazał się możliwy dzięki pomiarom wykonanym w jednym z otworów koncesji W, położonej w północnej Polsce (rysunek 1).

Geologicznie obszar ten należy do obrzeża basenu Morza Bałtyckiego. Obiektem poszukiwań jest formacja łupków sylursko-ordowickich, nasycona ropą i gazem, zalegająca na głębokości około $3 \mathrm{~km}$. Warstwy będące przedmiotem poszukiwań tektonicznie są spokojne i zalegają prawie horyzontalnie. Pewien problem interpretacyjny stanowią natomiast wyżej zalegające utwory cechsztyńskie. W wymienionym rejonie wykonano badania sejsmiki powierzchniowej $(2 \mathrm{D}$, a następnie 3D) i sejsmiki otworowej w wersji pomiarów pionowego profilowania sejsmicznego (PPS) oraz - co stanowi szczególnie ważną informację w problematyce modyfikacji charakterystyki spektralnej - pomiary prędkości fal podłużnych i poprzecznych (rysunek 2).

Zainteresowanie zastosowaniem fal poprzecznych, a właściwie sejsmiką wieloskładnikową (ang. multicomponent seismic) w poszukiwaniach przemysłowych i eksploatacji ropy i gazu fluktuuje $\mathrm{z}$ różnym nasileniem na przestrzeni już co 
a)

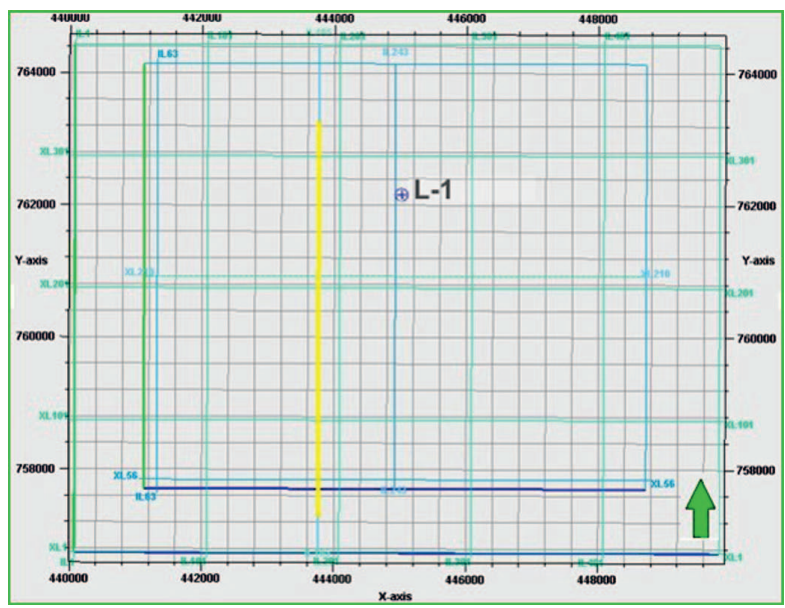

b)

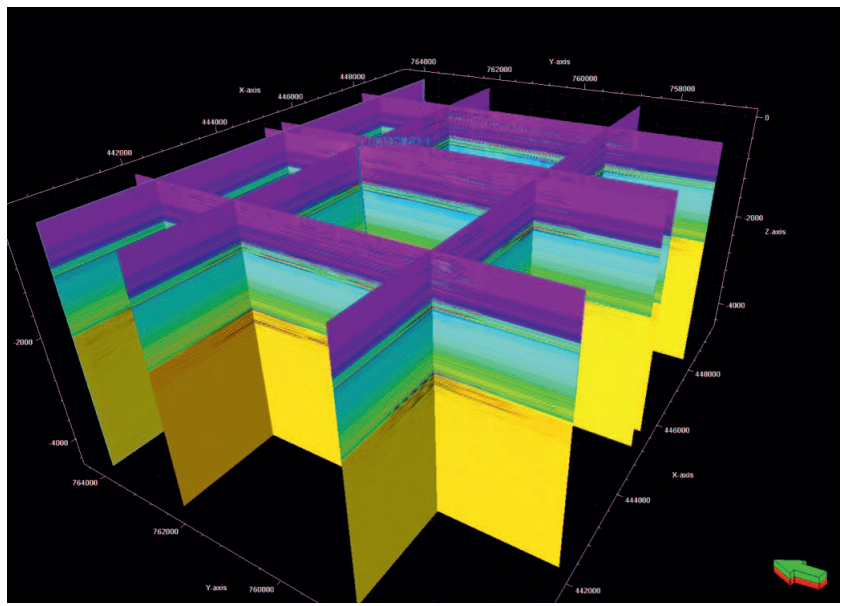

Rys. 1. Schemat lokalizacji profili (a) oraz wybrane profile (b) w wersji impedancji akustycznej

(a)

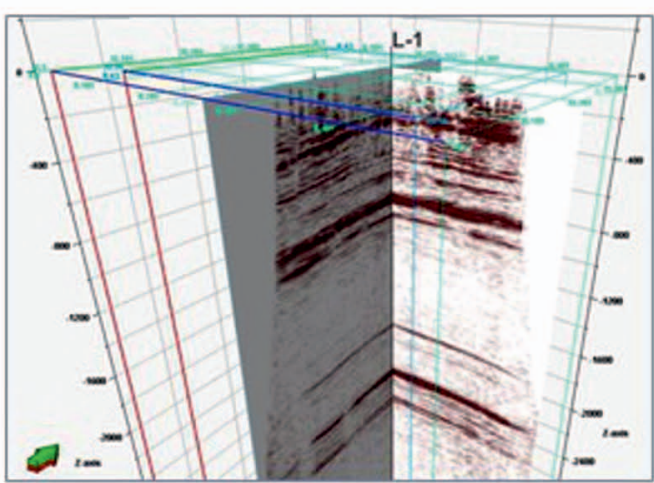

Wersjagłębokościowa [m] SXX (transwersalna)
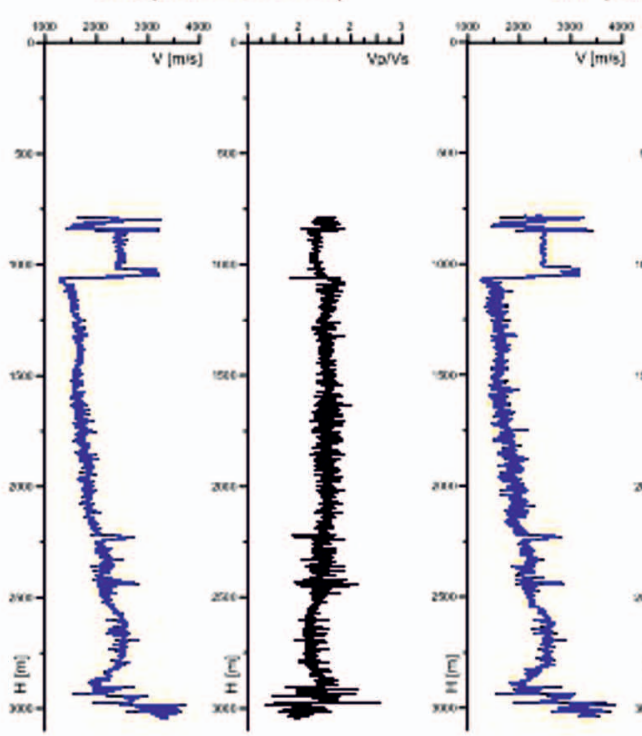
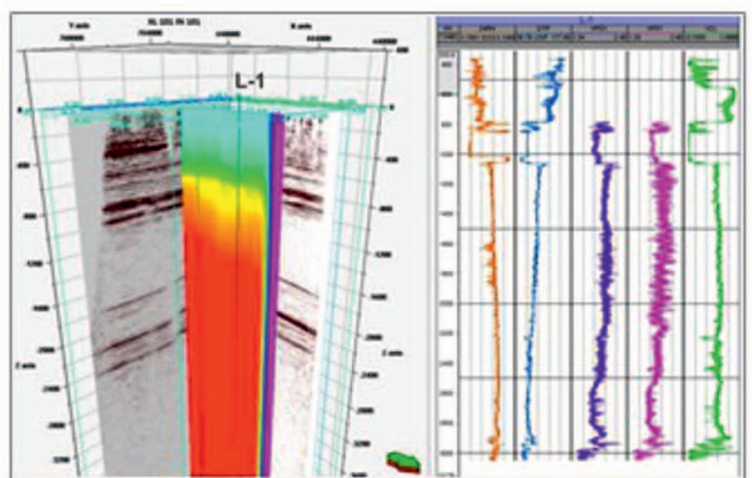

Wersjaczasowa [ms]

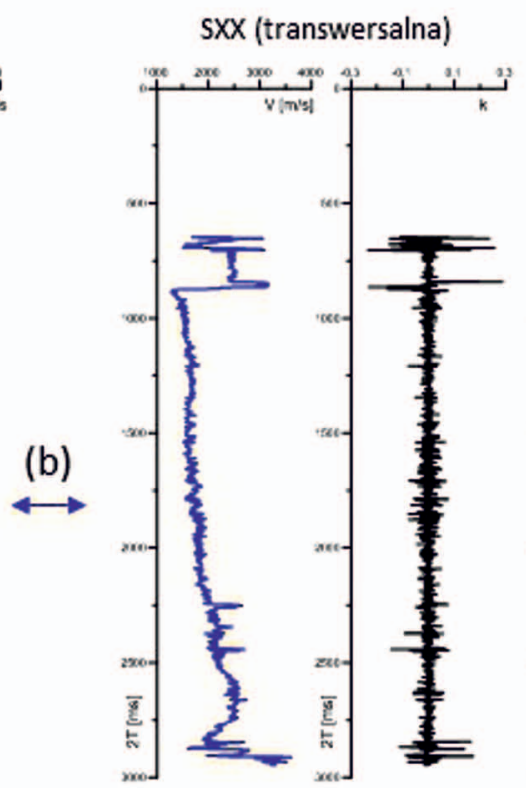

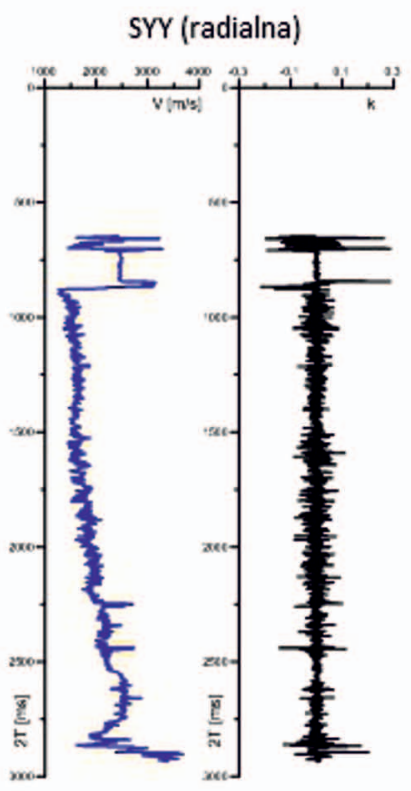

Rys. 2. Przykład zarejestrowanych danych sejsmicznych i otworowych (profile IL249 oraz XL272, fala podłużna odbita PP) i wyniki profilowania w otworze L-1 (a) oraz wyniki profilowania prędkości fali poprzecznej - składowa transwersalna i radialna w domenie głębokości i czasu wraz z krzywą relacji $V_{p} / V_{s}$ (b)

najmniej dwóch dziesięcioleci [1, 14, 18, 22, 24], a spowodowane zostało w skali światowej zdefiniowaniem problematyki zbiornikowej charakterystyki obiektów złożowych (ang. reservoir characterization problem). Wyjaśnienie przy- czyn takiego ukierunkowania badań jest bardzo proste - w ramach charakterystyki zbiornikowej opisujemy właściwości fizyczne zarówno skały zbiornikowej, jak i płynów nasycających (wody, ropy i gazu), jak też, a może przede wszyst- 
kim, lokalizujemy położenie obiektów zbiornikowych i oceniamy ich potencjał energetyczny.

Wyjątkowość w tym zakresie fal poprzecznych polega na tym, że propagująca fala skręceniowa poprzeczna $\mathrm{S}$ reaguje w sposób istotnie różny na właściwości wymienionych mediów (ciało stałe-skała i płyny nasycające) w porównaniu do objętościowej fali podłużnej P. Najistotniejszymi parametrami diagnostycznymi są tu prędkości propagacji fal $\mathrm{P}$ i S: $V_{p}[\mathrm{~m} / \mathrm{s}], V_{s}[\mathrm{~m} / \mathrm{s}]$, związane z gęstością ośrodka $\rho\left[\mathrm{g} / \mathrm{cm}^{2}\right]$ poprzez moduł sprężystości objętościowej $K$ (ang. constrained modulus, bulk modulus): $V_{p}=f \sqrt{K / \rho}$ oraz moduł sprężystości poprzecznej (skręceniowy) $G$ (ang. shear modulus): $V_{s}=f \sqrt{G / \tilde{n}}$.

Relacja powyższych prędkości definiowana jest poprzez bezwymiarowy współczynnik Poissona $v: V_{p} / V_{s}=\sqrt{\frac{1-v}{0,5-v}}$; $v=0,5 \frac{\left(V_{p} / V_{s}\right)^{2}-2}{\left(V_{p} / V_{s}\right)^{2}-1}$.

Moduły $K$ i $G$ wyrażone są w jednostkach ciśnienia Pa, bar i psi $\left(1 \mathrm{~Pa}=10^{-5}\right.$ bar $\left.=0,000145 \mathrm{psi}\right)$.

Różne wartości prędkości propagacji fal podłużnych i poprzecznych wynikają z ich odmiennych właściwości oraz różnego sposobu propagacji tych fal w ośrodku. I właśnie ze względu na różną reakcję podczas propagacji w ośrodku stałym (ang. solids) oraz w płynach (ang. fluids) fale poprzeczne są wrażliwe na rodzaj i wielkość nasycenia płynami złożowymi [13, 20, 23]. W przypadku fali podłużnej kierunek propagacji fali jest zgodny z kierunkiem drgań poddanego naprężeniom ośrodka. Fala poprzeczna, ulegająca polaryzacji przy przejściu podczas propagacji do ośrodka o różnych wła-
Ośrodek izotropowy (a)
$\mathrm{i}$ anizotropowy (b)
$\mathrm{z}$ ukierunkowanym
Tworzenie się fali S
rozkładem cząstek

ściwościach fizycznych, propaguje w kierunku prostopadłym do drgań ośrodka, wywołanych działającymi tu naprężeniami. Ponadto na skutek dwójłomności (ang. birefringence) rozdziela się na dwie wzajemnie prostopadłe składowe, transwersalną i radialną. Charakterystyka tych dwóch propagujących fal poprzecznych (kierunek i prędkość) zależy od parametrów fizycznych ośrodka, co pokazane jest dość prosto na rysunku 3.

Różnice prędkości propagacji dwóch różnie spolaryzowanych fal poprzecznych są wynikiem relacji kierunku polaryzacji fal oraz dominującego kierunku anizotropii lub uporządkowanej niejednorodności. Oczywiste jest, że składowa fali propagująca wzdłuż kierunku kompakcji ziaren będzie charakteryzować się większą prędkością, stąd nazwa „składowa szybka - FAST" (większa część drogi przypada na ciało stałe), niż składowa fali, która propagować będzie część drogi $\mathrm{w}$ przestrzeni międzyziarnowej, a więc $\mathrm{z}$ utrudnionym transferem energii, stąd nazwa ,składowa wolna - SLOW”. Z powyższego wynika, że jeszcze trudniejsze warunki przekazu energii występują w przypadku obecności płynów w ośrodku.

W dziedzinie sejsmologii od dawna znane jest wykorzystanie fal poprzecznych [1, 3], między innymi w celu predykcji trzęsień ziemi i erupcji wulkanicznych [2]. Do dziedziny sejsmiki, szczególnie w zastosowaniu do poszukiwań ropy i gazu, dotarło znacznie później [24] i od tej chwili w sposób ciągły dostarcza bezcennych informacji na temat zachowania się obiektów złożowych. Wspomniane wyżej dwie składowe spolaryzowanej fali poprzecznej, zależnie od geometrii rozkładu parametrów fizycznych ośrodka i zastosowanego schematu akwizycji, określane jako szybka (ang. FAST) i wolna (ang. $S L O W$ ), stanowią jedno z najsilniejszych narzędzi diagnostycznych badania anizotropii w ośrodku.
Objaśnienie powstania różnicy czasów fali szybkiej i wolnej
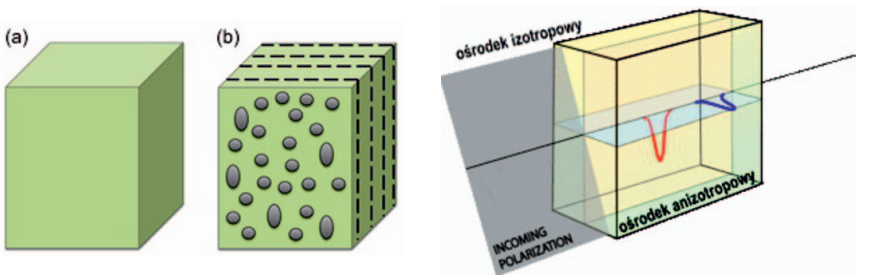

Diagram propagacji dwóch wzajemnie prostopadłych, spolaryzowanych fal $\mathrm{S}$ w ośrodku anizotropowym

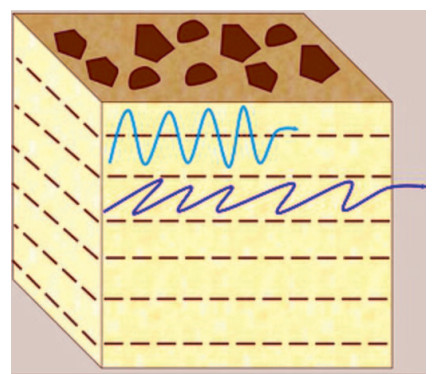

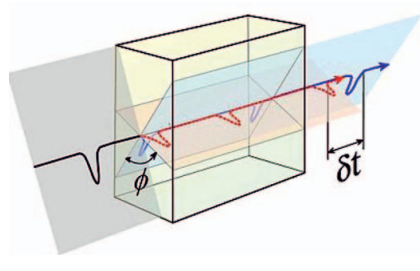

Rys. 3. Poglądowa ilustracja reakcji spolaryzowanej fali poprzecznej przechodzącej z ośrodka izotropowego do anizotropowego (według https://en.wikipedia.org/wiki/Shear_wave_splitting; zmienione)

\section{Zarys sekwencji badawczej}

Dysponując opisanymi powyżej danymi w postaci sekcji sejsmicznych i krzywych otworowych (rysunki 1 i 2), zaapli- kowano, zgodnie z pokazanym schematem (rysunek 4), opracowaną wcześniej sekwencję procedur modyfikacji $[4,5,9]$ 
ZAŁOŻENIE PROJEKTU

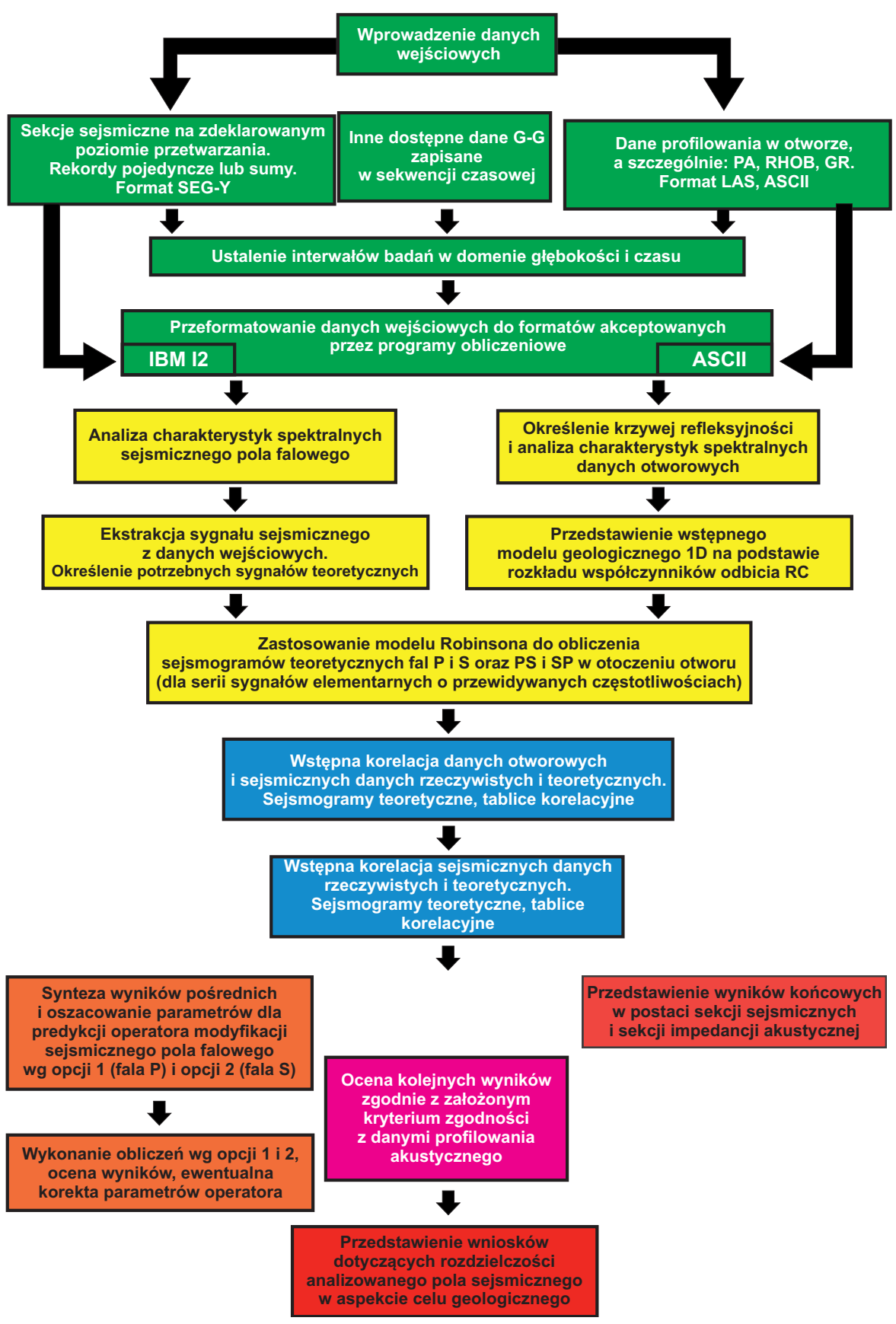

Rys. 4. Schemat ideowy zastosowania oprogramowania w procedurach modyfikacji zespolonej charakterystyki spektralnej sejsmicznego pola falowego
Na rysunku 5 pokazano widma amplitudowe i fazowe tras sejsmicznych, obliczone w interwałach czasowych zgodnie z rosnącą głębokością. Zwraca uwagę kształtowanie się zakresu częstotliwości dominujących wraz ze wzrastającym czasem rejestracji, od przedziału $37 \div 50 \mathrm{~Hz} \mathrm{w}$ oknie $0 \div 816 \mathrm{~ms}$, poprzez przedział $40 \div 70 \mathrm{~Hz}$ w oknie $1604 \div 2502 \mathrm{~ms}$, a kończąc na przedziale $30 \div 50 \mathrm{~Hz}$ w oknie $0 \div 4398 \mathrm{~ms}$, co potwierdza znany fakt tłumienia wyższych częstotliwości wraz z rosnącą głębokością penetracji drgań. Najpełniejszy zakres częstotliwości obserwuje się dla okna do 2500 ms, z czego wynika, że zwiększenie rozdzielczości sekcji sejsmicznej wymaga zwiększenia przedziału częstotliwości (poprzez modyfikację) co najmniej do wartości $75 \mathrm{~Hz}$.

Analogiczne obliczenia przeprowadzono na krzywych refleksyjności, obliczonych z krzywych profilowania prędkości fali PP (rysunek 6).

Zwiększenie okna analizy skutkuje bogatszym zbiorem częstotliwości. Charakterystyczne zakresy częstotliwości dominujących odpowiadają wartościom obserwowanym dla wejściowej sekcji sejsmicznej $(50 \mathrm{~Hz})$. Ponadto wyraźnie zaznacza się przedział częstotliwości $100 \div 150 \mathrm{~Hz}$, co sugeruje, że podniesienie rozdzielczości danych sejsmicznych do rozdzielczości bliskich danym otworowym wymaga rozszerzenia charakterystyki spektralnej do częstotliwości rzędu $100 \div 130 \mathrm{~Hz}$, a więc jeszcze bardziej dobitnie potwierdza potrzebę modyfikacji charakterystyk spektralnych sejsmicznego pola falowego na podstawie danych sejsmiki powierzchniowej i otworowej (rysunek 5). Nowym elementem w obecnie prezentowanej koncepcji jest uwzględnienie możliwości wykorzystania do predykcji operatora modyfikacji spektralnej pomiarów prędkości w otworze nie tylko fal podłużnych, ale również fal poprzecznych. Zgodnie z przedstawionym schematem (rysunek 4) etap początkowy to założenie projektu i uzgodnienia formatów (obszar zielony), a następnie zmienna w czasie analiza spektralna obrazu falowego, prowadzona równolegle na danych sejsmiki powierzchniowej i otworowej (obszar żółty). danych sejsmicznych.

W dalszej kolejności przeprowadzono badania charakterystyk spektralnych i określenia operatora modyfikacji na podstawie krzywych refleksyjności obliczonych z profilowania prędkości składowych radialnej i transwersalnej fali skręceniowej (rysunek 7).

Zaprezentowane na rysunku 7 widma kompleksowe potwierdzają prawidłowość wyższej wartości częstotliwości dominującej spektrum fali S $\sim 100 \mathrm{~Hz}$ w stosunku do $45 \mathrm{~Hz}$ dla fali P oraz zróżnicowania obrazu spektralnego składowych radialnej i transwersalnej (103 Hz dla składowej SX 


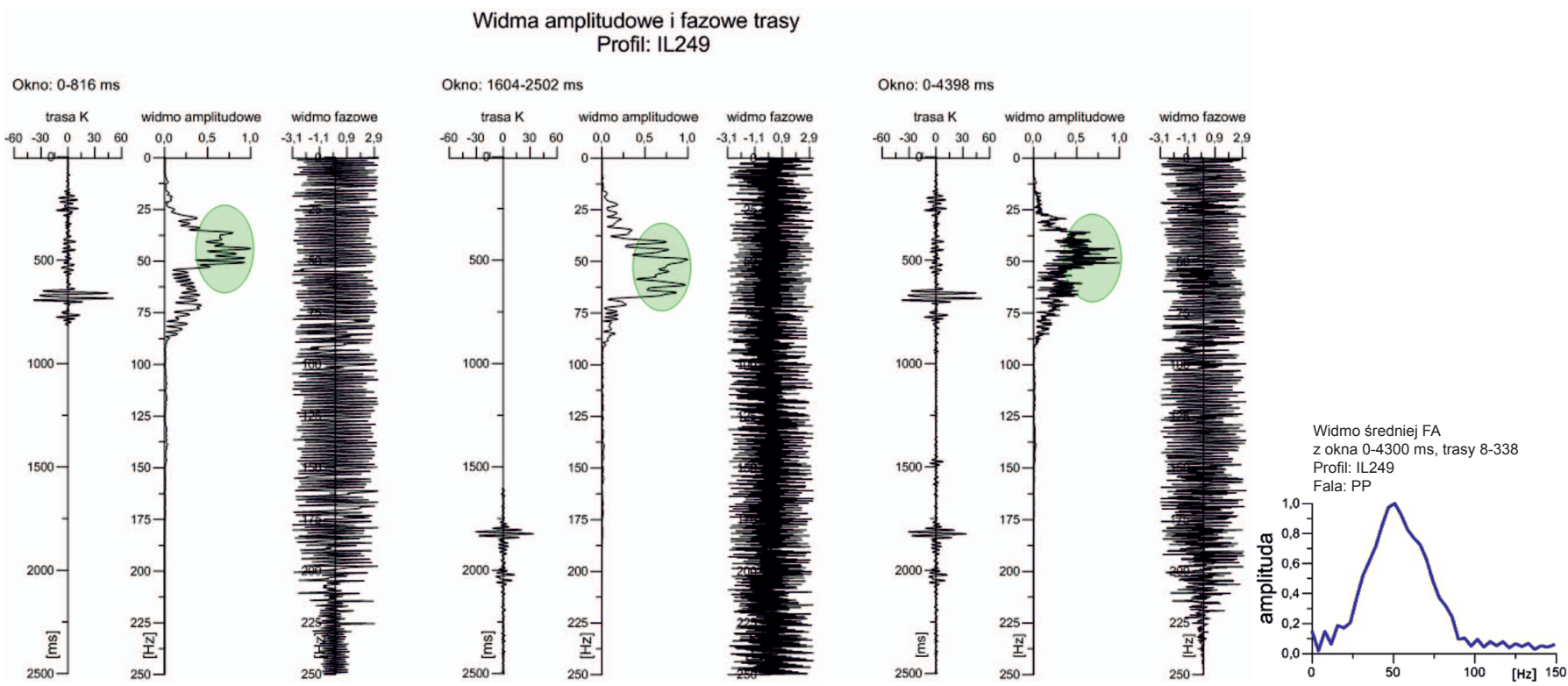

Rys. 5. Analiza charakterystyk spektralnych pola falowego fali podłużnej PP w zmieniających się interwałach czasowych

(okna: 0 $\div 816 \mathrm{~ms}, 1604 \div 2502 \mathrm{~ms}, 0 \div 4398 \mathrm{~ms}$ ). Profil IL249. Dane wejściowe (PSTM)

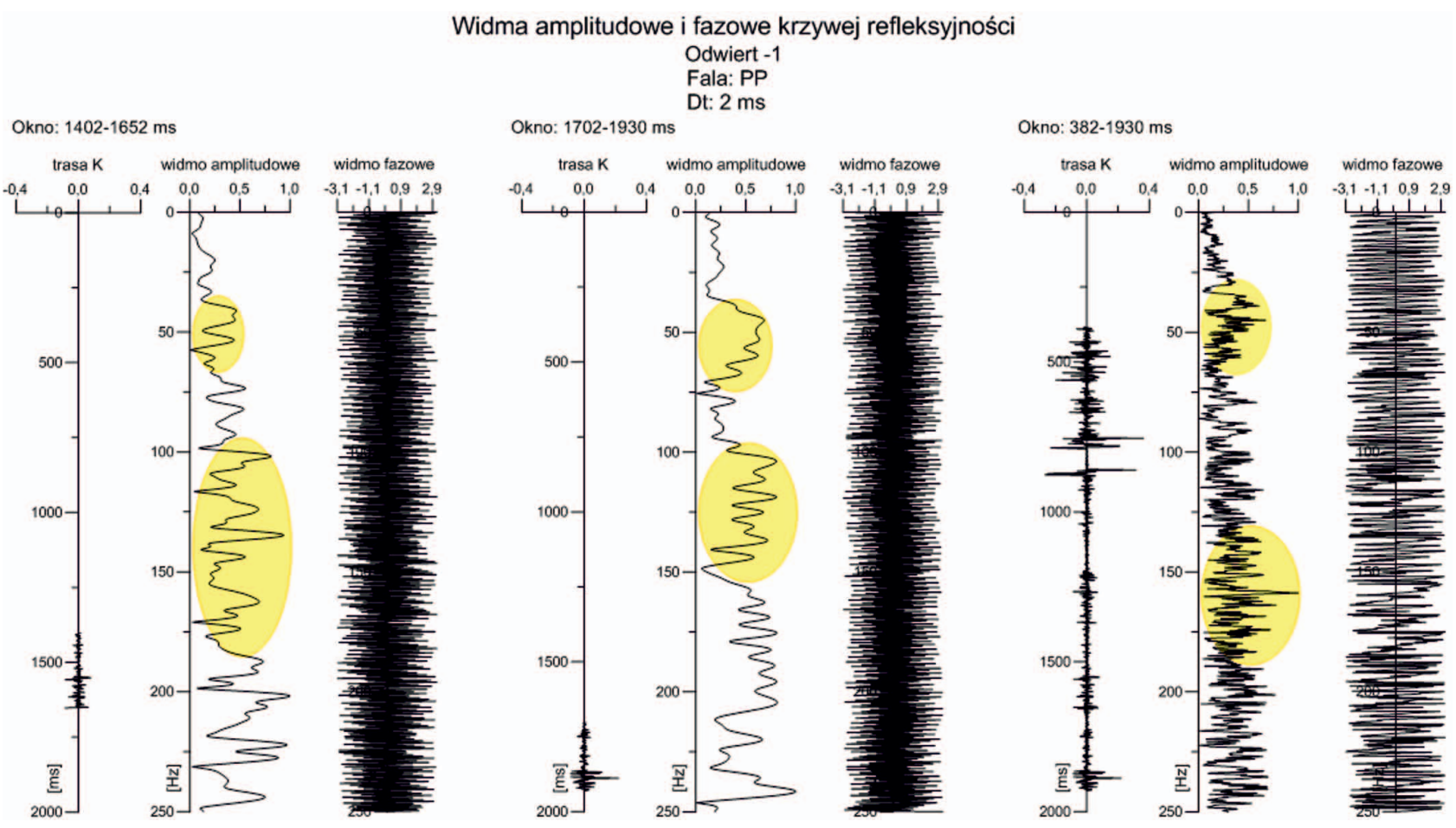

Rys. 6. Charakterystyka spektralna krzywych refleksyjności utworzonych na podstawie

prędkości propagacji fali podłużnej w otworze

oraz $112 \mathrm{~Hz}$ dla składowej SY), co jest bardzo ważną cechą diagnostyczną, np. w ocenie występowania anizotropii.

Powyższe analizy umożliwiły obliczenie operatora (rysunek 8) i przeprowadzenie modyfikacji spektralnej, której wyniki przedstawiono na rysunku 9.

Wyraźnie wyodrębniona jest grupa częstotliwości z dominująca wartością około $100 \mathrm{~Hz}$, których nie obserwuje się w sejsmicznych danych wejściowych (rysunek 5), natomiast wyraźnie są obecne w danych otworowych (rysunek 6).
Ta grupa wysokich częstotliwości pojawia się na polu falowym po kolejnych modyfikacjach spektralnych. Szczególnie należy podkreślić obecność częstotliwości rzędu $100 \mathrm{~Hz}$ w dwóch czasowo odległych interwałach: 818 $\div 1290 \mathrm{~ms} \mathrm{oraz}$ $2504 \div 3998$ ms, co świadczy o możliwości odtworzenia wysokoczęstotliwościowej frakcji charakterystyki spektralnej występującej w strefie wzbudzenia. Jak wiadomo, ta część spektrum jest najsilniej pochłaniana i negatywnie wpływa na rozdzielczość. Najczęściej ten fakt stanowi przyczynę 
Składowa PZ

Okno: $1702-1930 \mathrm{~ms} \rightarrow$
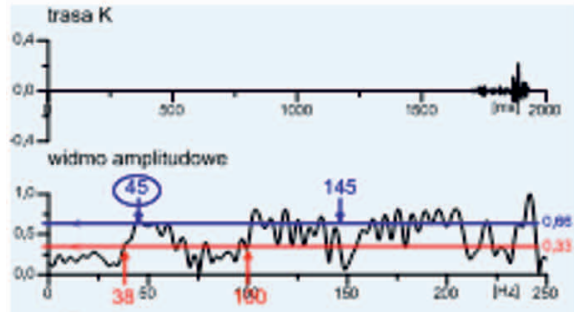

widmo fazone

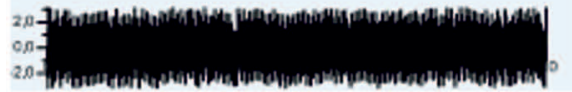

Rys. 7. Charakterystyki spektralne krzywych refleksyjności obliczonych z profilowania prędkości fal podłużnych i poprzecznych w odwiercie L-1 w wybranych interwałach czasowych
Widmo amplitudowe i fazowe operatora modyfikacji PZO

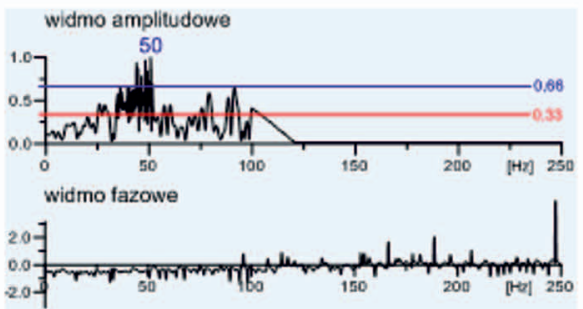

Składowa SX
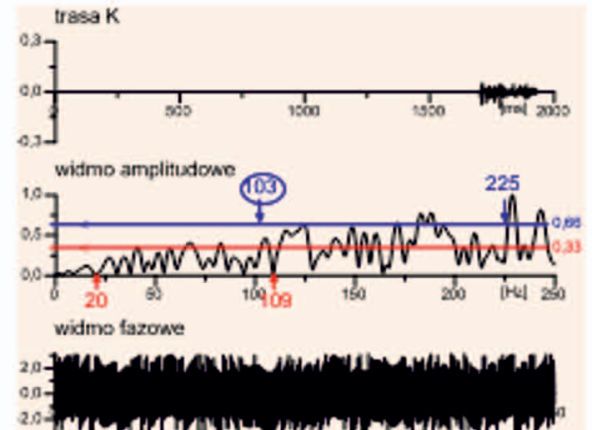

Składowa SY
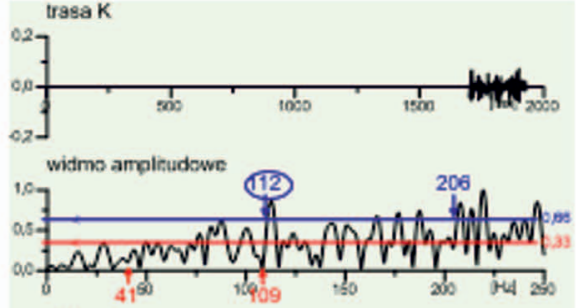

widma fazose

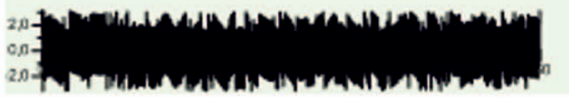

Rys. 8. Charakterystyki spektralne operatorów modyfikacji obliczonych na podstawie analizy danych otworowych fal podłużnych i poprzecznych
PZO

Okno: $818-1298 \mathrm{~ms}$
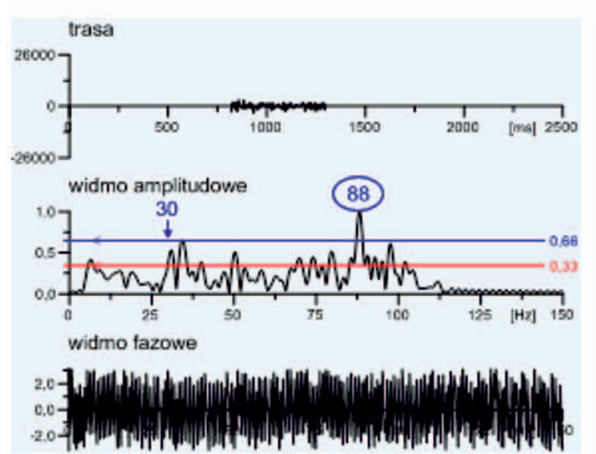

Okno: $2504-3998 \mathrm{~ms}$
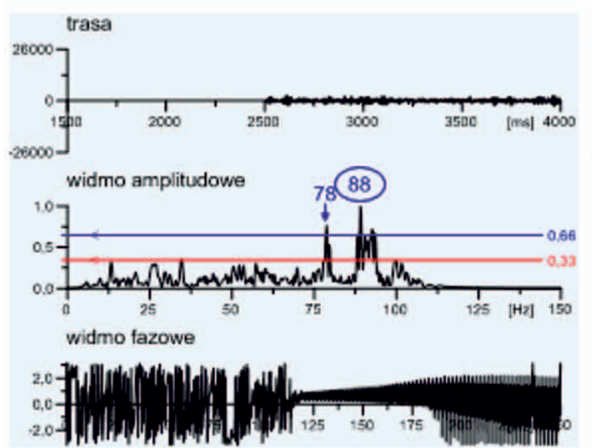

Widmo amplitudowe i fazowe operatora modyfikacji SXO

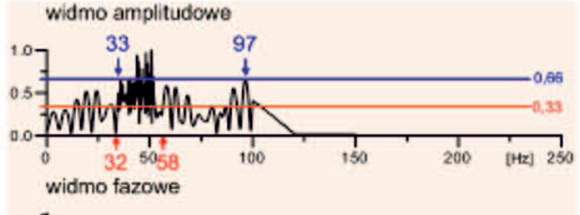

200 .
Widmo amplitudowe i fazowe operatora modyfikacji SYO

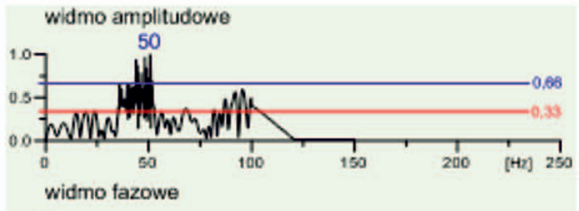

207 
nieprawidłowej interpretacji, szczególnie formacji geologicznych głęboko zalegających. Ta część analiz nadal prowadzona jest w ramach obszaru „żółtego” - na pokazanym schemacie (rysunek 4).
Dla potwierdzenia powyższych obserwacji obliczono dodatkowo widma funkcji autokorelacji (FA) w szerokim oknie $150 \div 3800$ ms rejestracji fal podłużnych, po zaaplikowaniu różnych operatorów modyfikacji (rysunek 10).
Sekcja INPUT

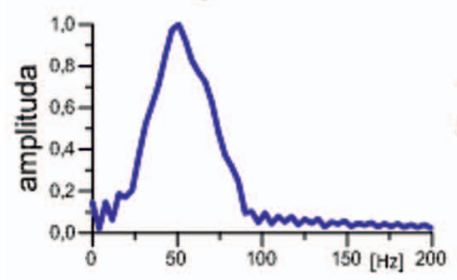

PZ

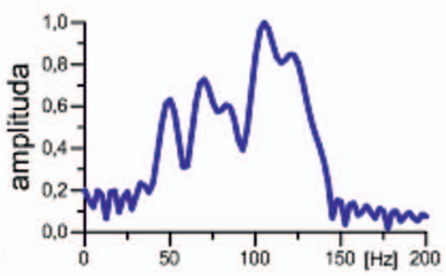

\section{Sekcje po modyfikacji spektralnej}

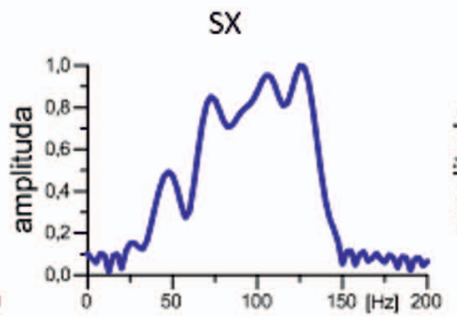

SY

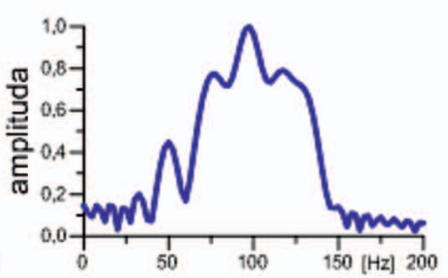

Rys. 10. Widma średniej FA z okna 150 $\div 3800 \mathrm{~ms}$, trasy 1 $\div 385$. Profil IL249 po modyfikacji spektralnej według operatorów obliczonych z wykorzystaniem składowych: pionowej fali podłużnej (PZ) oraz poziomych transwersalnej (SX) i radialnej (SY) - zarejestrowanych w otworze wraz z widmem FA sekcji wejściowej

\section{Wykorzystanie modelowania sejsmicznego do oceny poprawności proponowanych rozwiązań}

Dla potwierdzenia słuszności powyższego rozumowania analogiczne analizy przeprowadzono na danych modelowych [11, 20,21]. Wykorzystując analizowane materiały sejsmiczne i aplikując inwersję sejsmiczną na danych wejściowych oraz po modyfikacji spektralnej, zbudowano model prędkościowo-głębokościowy. Uzyskano w ten sposób dwie wersje modelu geologicznego różniące się rozdzielczością, czyli najmniejszą możliwą do odtworzenia miąższością warstw badanej formacji (rysunek 11).

Obliczony sejsmogram teoretyczny w wersji czasu pionowego potraktowano jako testowy model konwolucyjny; przyjęto sygnał elementarny symetryczny o częstotliwości $50 \mathrm{~Hz}$,

\section{Dane sejsmiczne wykorzystane do opracowania modelu geologicznego (grubowarstwowy i cienkowarstwowy)}

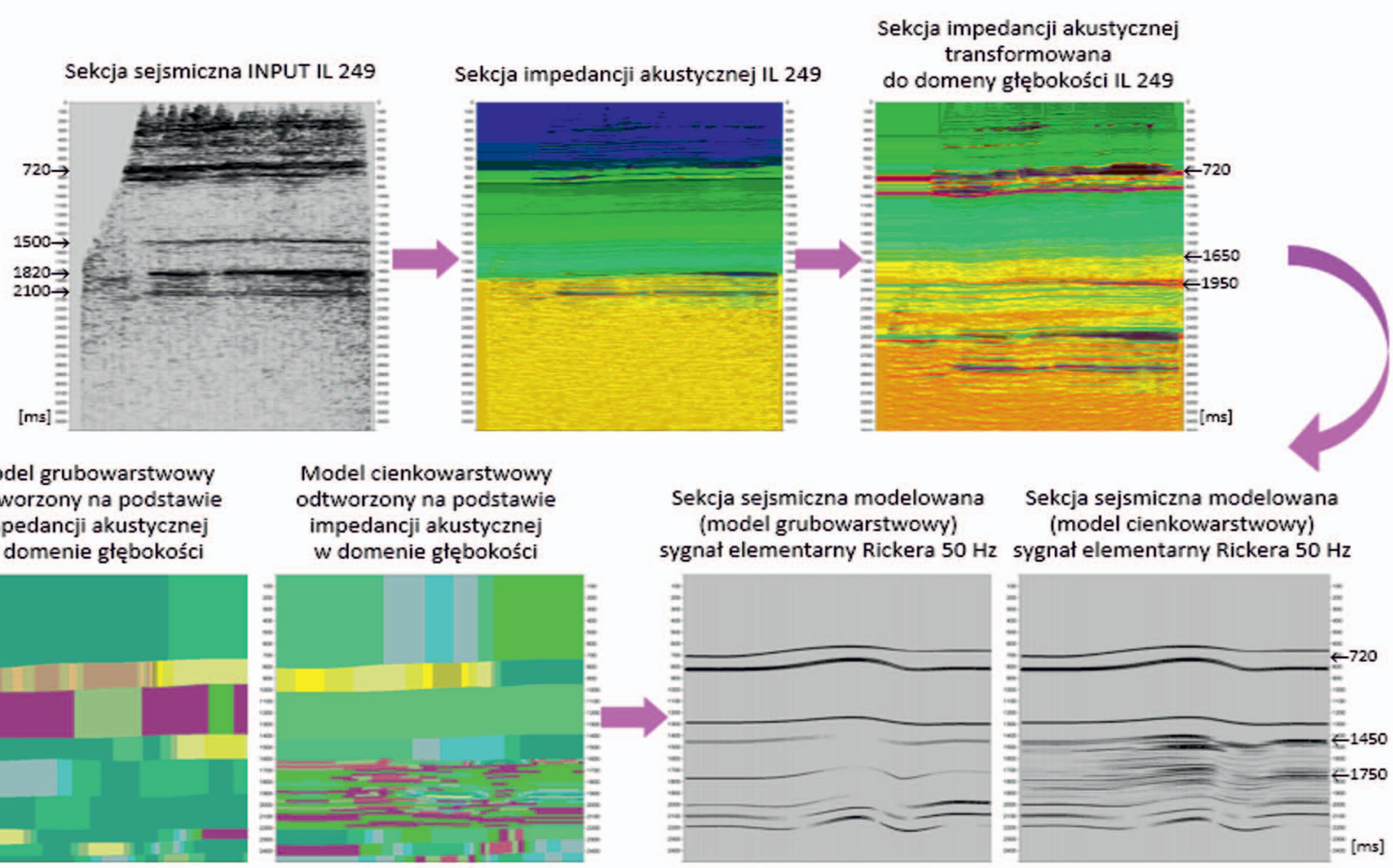

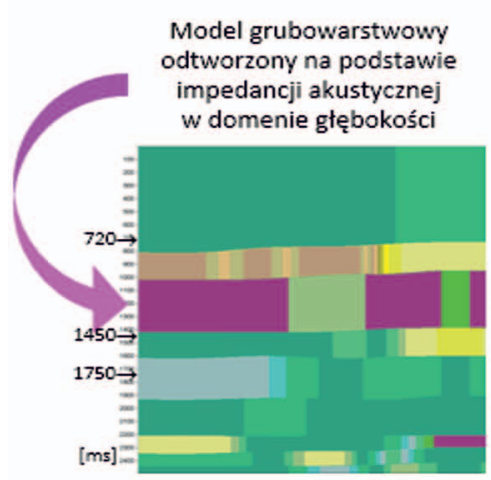

Rys. 11. Sekwencja tworzenia modelu geologicznego 
a więc takiej, jaka najczęściej obserwowana jest na sekcji wejściowej (PSTM). Poprawa rozdzielczości widoczna w wynikach inwersji sejsmicznej modelu cienkowarstwowego w stosunku do modelu grubowarstwowego, jak też w wynikach modelowania sejsmicznego w postaci sejsmogramów teoretycznych potwierdza skuteczność zastosowanej modyfikacji spektralnej.

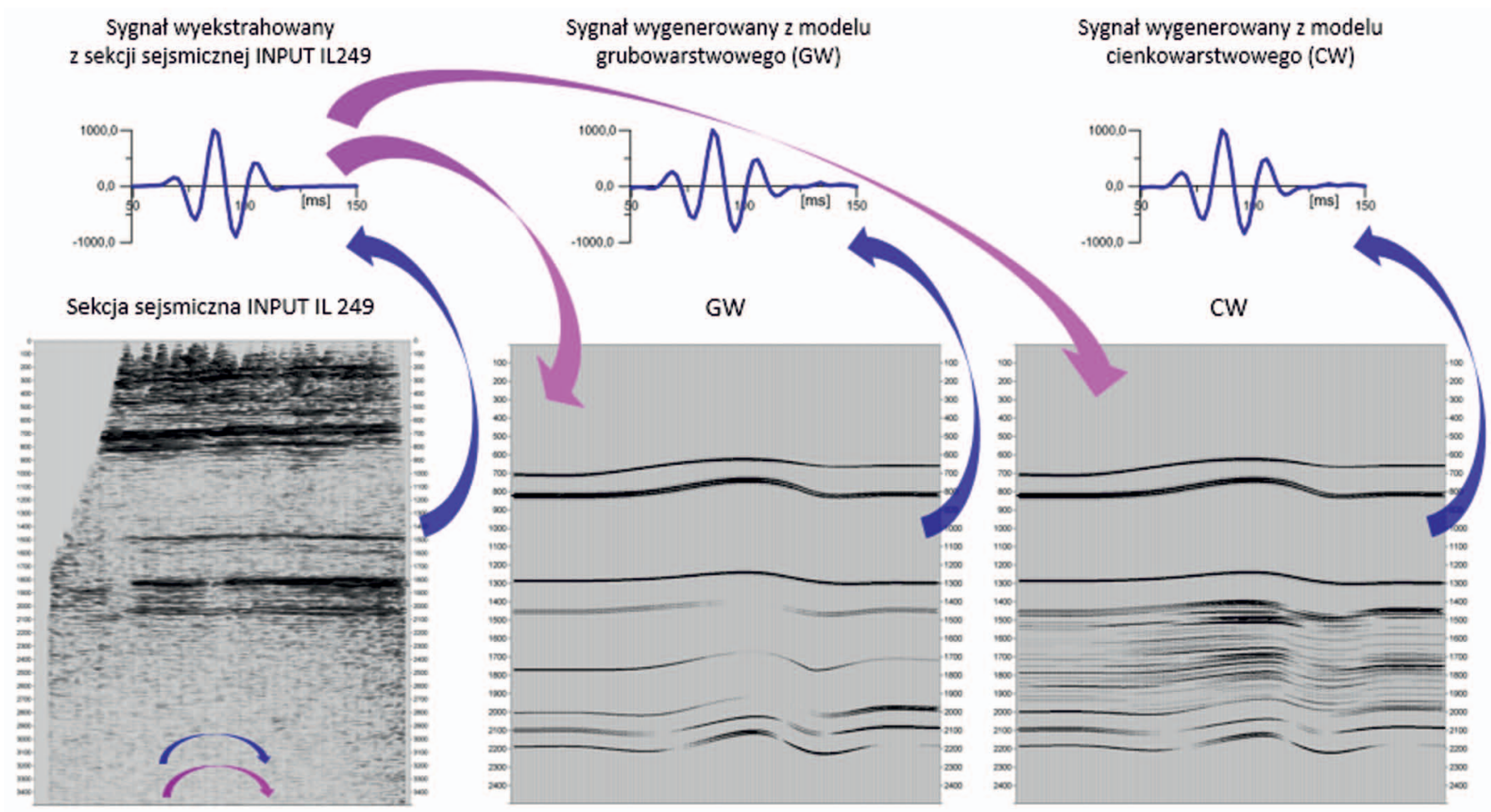

Rys. 12. Porównanie sygnałów elementarnych wyekstrahowanych z sekcji rzeczywistej IL249 oraz z modeli grubo- $(\mathrm{GW})$ i cienkowarstwowego $(\mathrm{CW})$

\section{Widmo amplitudowe i fazowe sygnału wyekstrahowanego} z pliku INPUT IL249 okno: 0-254 ms
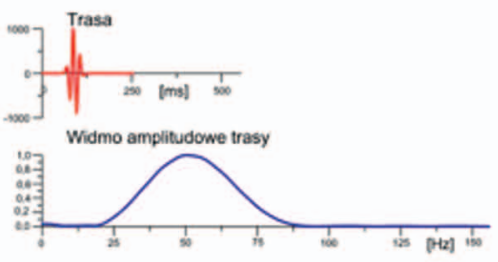

Widmo fazowe trasy

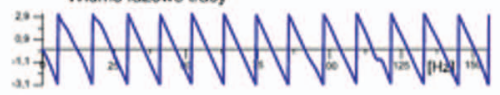

GW okno: 0-2498 ms

\section{Widmo amplitudowe i fazowe sygnału wyekstrahowanego $z$ pliku "Model grubowarstwowy"}

okno: 0-254 ms
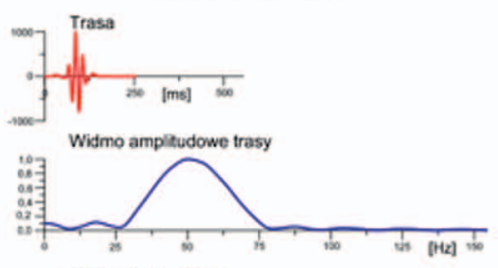

Widmo fazowe trasy

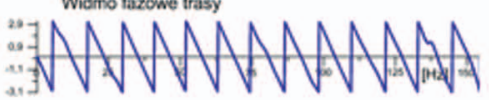

Widmo amplitudowe i fazowe sygnału wyekstrahowanego $z$ pliku "Model cienkowarstwowy" okno: 0-254 ms

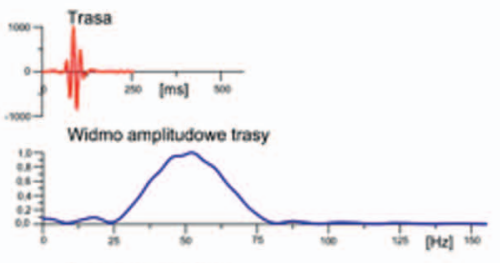

Widmo tazowe trasy

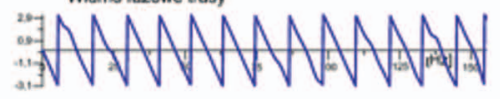

CW
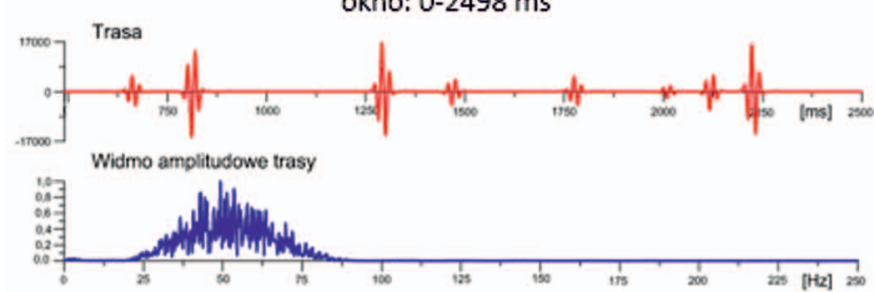

Widmo fazowe trasy

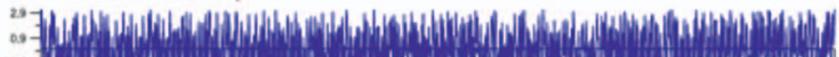

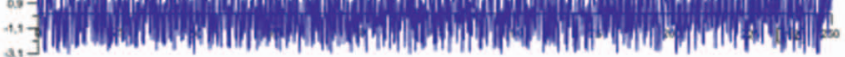

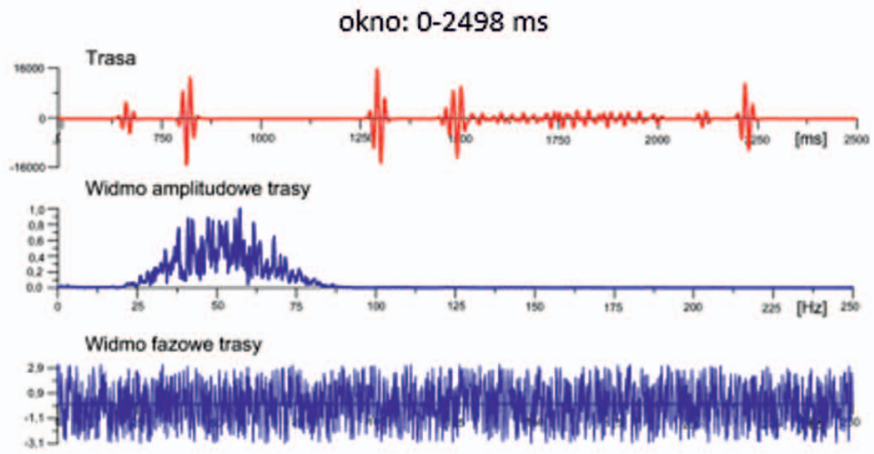

Rys. 13. Fragmenty tras rzeczywistej i teoretycznych obliczanych dla modeli grubo- i cienkowarstwowego oraz ich charakterystyki spektralne w oknach $0 \div 254 \mathrm{~ms}$ i $0 \div 2498 \mathrm{~ms}$ 
W dalszej kolejności wyekstrahowano sygnały z sekcji rzeczywistej i sekcji teoretycznych, co pozwoliło na ocenę ewentualnego błędu estymacji (rysunek 12) operatora modyfikacji.

Bardzo zbliżony kształt sygnałów pozwala zaakceptować obliczony model teoretyczny i wynikające charakterystyki spektralne (rysunek 13).

$\mathrm{Na}$ podstawie danych profilowania prędkości fal $\mathrm{P}$ i S obliczono krzywe refleksyjności (rysunek 14) i zestawiono trasy współczynników odbicia obliczone z pomiarów prędkości fal P i S w otworze w wersji splotu z sygnałami Rickera 20, 50 i $70 \mathrm{~Hz}$.

Obliczone trasy współczynników odbicia stanowią dane referencyjne dla późniejszych analiz i efektów aplikowania operatorów wyprowadzonych z fali S.

Kolejne etapy analizy charakterystyki spektralnej sejsmogramów teoretycznych (rysunek 15) komentują zmienność spektrum zależnie od sygnału elementarnego, a szczególnie znacznie wyraźniejsze niż w domenie czasowej zróżnicowanie wyników w domenie częstotliwości. Przedstawione porównania ułatwiają prowadzoną następnie analizę wyników na danych rzeczywistych.

Na pewno warto skomentować rozbudowywanie się szerokości widma wywołane zwiększaniem się częstotliwości sygnału elementarnego $\mathrm{z}$ równoczesnym zachowaniem parametrów spektrum wynikających z charakterystyki krzywej refleksyjności.

Przedstawione na rysunkach 14 i 15 wykresy współczynników odbicia oraz trasy sejsmogramów teoretycznych skłaniają do analizy wpływu i udziału dwóch czynników kształtujących sejsmogram teoretyczny według modelu Robinsona, tzn. krzywej refleksyjności i sygnału elementarnego. Krzywa refleksyjności jest tzw. informacją twardą, pomierzoną i uzyskaną z danych otworowych, niezmienną dla danego obiektu. Można więc sądzić, że ma decydujący wpływ na kształtowanie obrazu falowego. Analizę w powyższym zakresie przeprowadzono, obliczając korelację wybranych tras syntetycznych, różniących się aplikowanym sygnałem elementarnym, z sejsmogramu fali podłużnej w oknie $268 \div 1298 \mathrm{~ms}$.

Stwierdzono, że zmiana częstotliwości dominującej z $20 \mathrm{~Hz}$ do $50 \mathrm{~Hz}$ zmienia współczynnik korelacji do wartości 0,480 , natomiast z $20 \mathrm{~Hz}$ do $70 \mathrm{~Hz}$ - aż do wartości 0,288 . Z kolei korelacja tras w przedziale wyższych częstotliwości, tzn. $50 \mathrm{~Hz}$ i $70 \mathrm{~Hz}$, cechuje się znacznie wyższym współczynnikiem korelacji - o wartości 0,891. Analizę prowadzono dla przesunięć w zakresie korelowanego interwału na poziomie połowy wielkości okna.

Dość podobne wartości współczynników korelacji uzyskano dla tych samych sejsmogramów, ale w innym oknie: $1600 \div 2300 \mathrm{~ms}$, a więc w przedziale zdecydowanie różnego rozkładu współczynników odbicia. W analogicznej sekwencji jak uprzednio wartości są następujące: 0,282, 0,137 i 0,852. Stąd wniosek, że podobieństwo tras i ciągłość korelacji w silniejszym stopniu zależy od wartości sygnału elementarnego niż od rozkładu współczynników odbicia.

Analogiczne wnioski wynikają z obliczeń dla fal poprzecznych składowych SY i SX. W przypadku okna $698 \div 1798 \mathrm{~ms}$ (składowa SY) otrzymujemy wartości: 0,439-0,231-0,876; zaś w przypadku okna $1600 \div 2300$ ms podobnie: 0,335 $0,139-0,87$. Dla składowych SX w oknie $812 \div 1898 \mathrm{~ms}$ uzyskujemy następujące wartości: $0,466-0,239-0,812$ oraz wartości zbliżone w oknie $1600 \div 2300 \mathrm{~ms}: 0,279-0,181-0,882$.

Zbyt skromny zakres przeprowadzonych obliczeń nie upoważnia do daleko idących wniosków. Jednak należy pamiętać, że krzywe refleksyjności fali podłużnej i fal poprzecznych to w sekwencji czasowej dwa różne rozkłady wartości współczynnika odbicia.

Stąd ostrożnie obecnie traktowany wniosek, że dobra korelacja horyzontów, przez dziesięciolecia uważana za niezbity dowód poprawności interpretacji, może być wynikiem wielu przypadkowych efektów, a szczególnie interferencji.

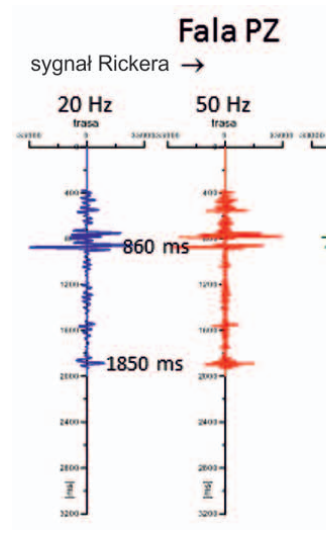

Fala SX

Fala SY

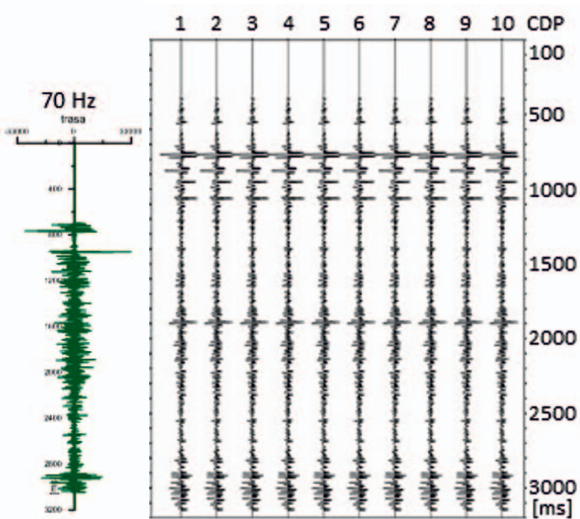

Rys. 14. Trasy współczynników odbicia dla fali P i fal S oraz zbiorczy sejsmogram teoretyczny pełnego pola sejsmicznego fal sprężystych 
a)

Koncesja Wejherowo. Odwiert L-1. Sejsmogramy teoretyczne. Widma amplitudowe i fazowe. Fala PP, składowa pionowa

Sygnał Rickera $20 \mathrm{~Hz}$

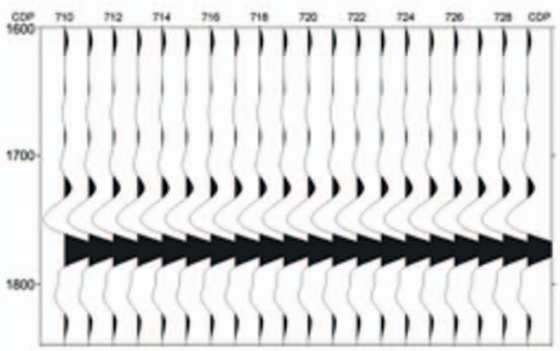

Sygnał symetryczny $20 \mathrm{~Hz}$

Okno: $1600-1882 \mathrm{~ms}$
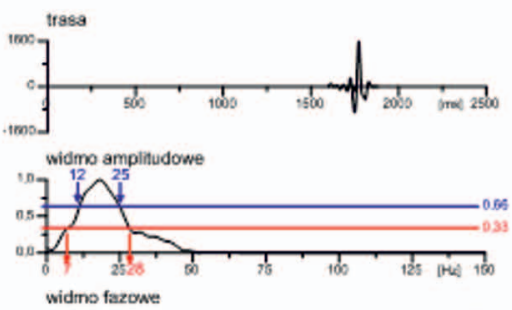

widmo fazone

${ }_{2,0}^{2,0}$ A
Sygnał Rickera $50 \mathrm{~Hz}$

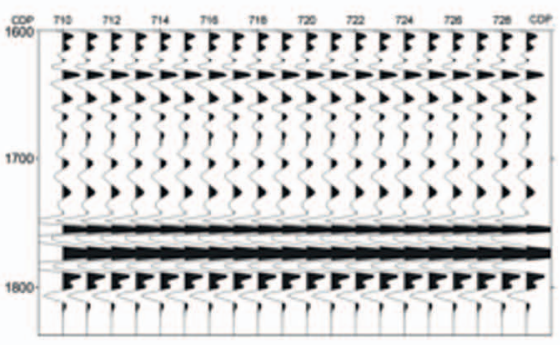

Sygnał symetryczny $50 \mathrm{~Hz}$

Okno: $1600-1834 \mathrm{~ms}$
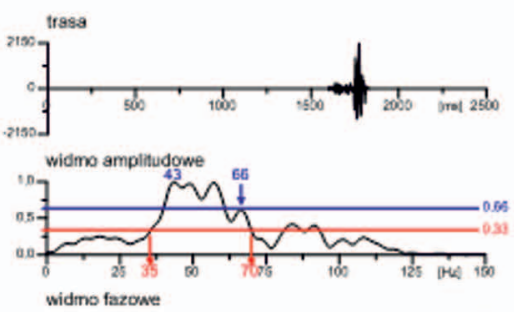

${ }^{2,0}$ -

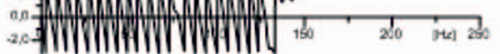

Sygnał Rickera $70 \mathrm{~Hz}$

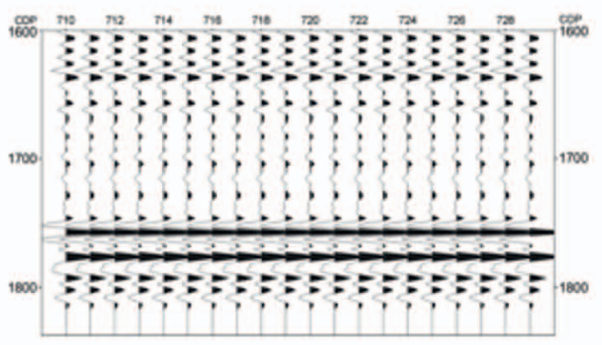

Sygnał symetryczny $70 \mathrm{~Hz}$

Okno: $1600-1830 \mathrm{~ms}$
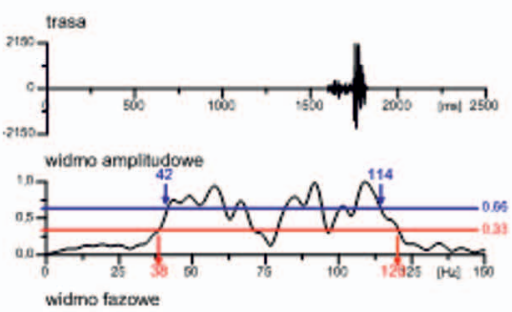

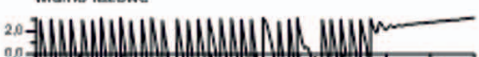

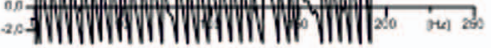

b) Koncesja Wejherowo. Odwiert L-1. Sejsmogramy teoretyczne. Widma amplitudowe i fazowe. Fala S, składowa transwersalna SXX

Sygnał Rickera $20 \mathrm{~Hz}$

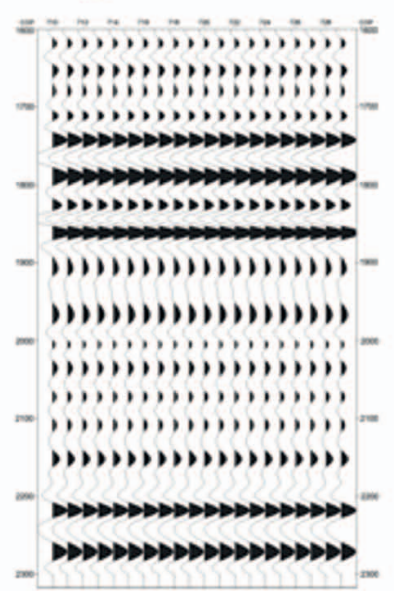

Sygnał symetryczny $20 \mathrm{~Hz}$ Okno: $1600-2300 \mathrm{~ms}$
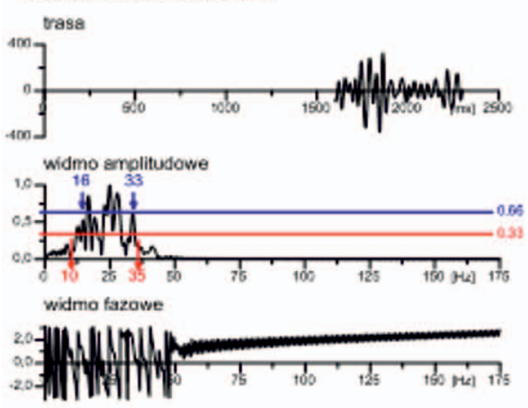

Sygnał Rickera $50 \mathrm{~Hz}$

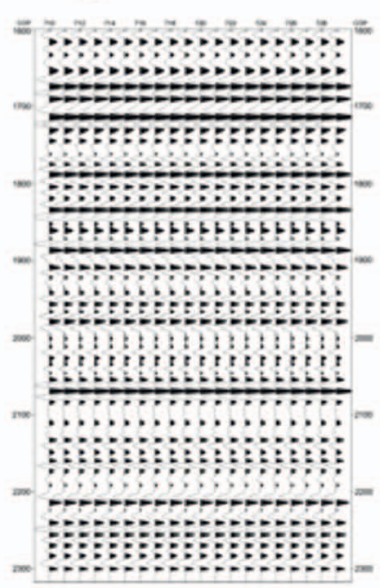

Sygnał symetryczny $50 \mathrm{~Hz}$

Okno: $1600-2300 \mathrm{~ms}$
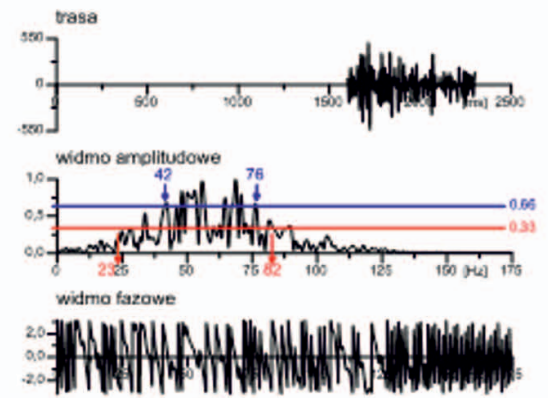

Sygnał Rickera $70 \mathrm{~Hz}$

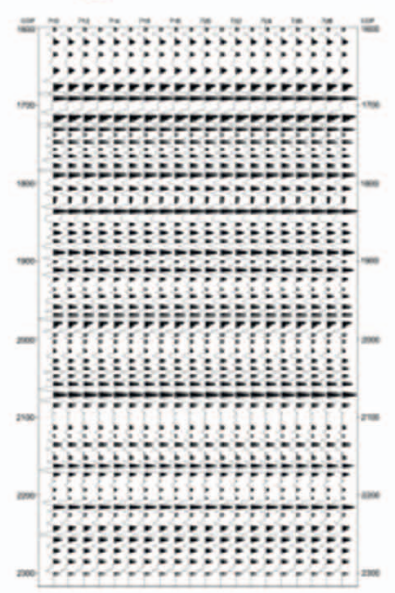

Sygnał symetryczny $70 \mathrm{~Hz}$ Okno: 1600-2300 ms
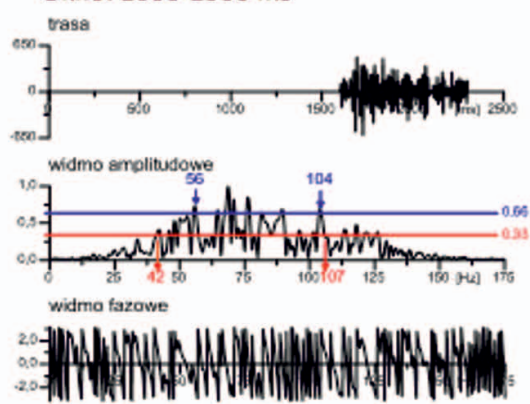
c)

Koncesja Wejherowo. Odwiert L-1. Sejsmogramy teoretyczne. Widma amplitudowe i fazowe. Fala S, składowa radialna SYY

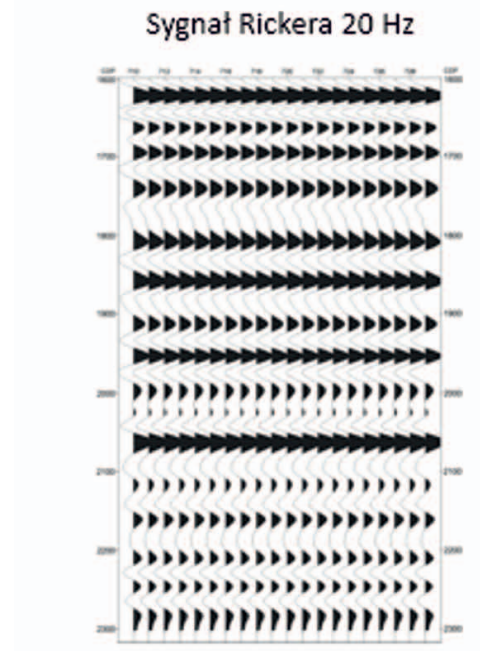

Sygnał symetryczny $20 \mathrm{~Hz}$ Okno: $1600-2300 \mathrm{~ms}$
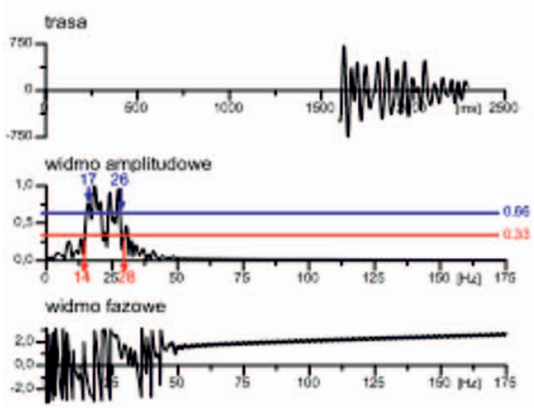

Sygnał Rickera $50 \mathrm{~Hz}$

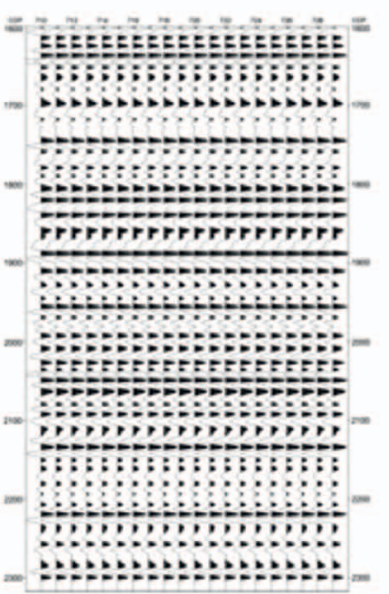

Sygnał symetryczny $50 \mathrm{~Hz}$ Okno: $1600-2300 \mathrm{~ms}$
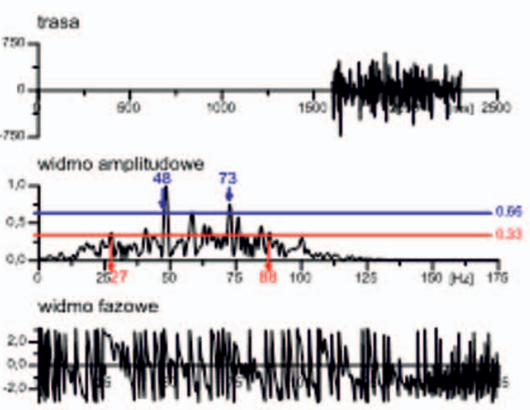

Sygnał Rickera $70 \mathrm{~Hz}$

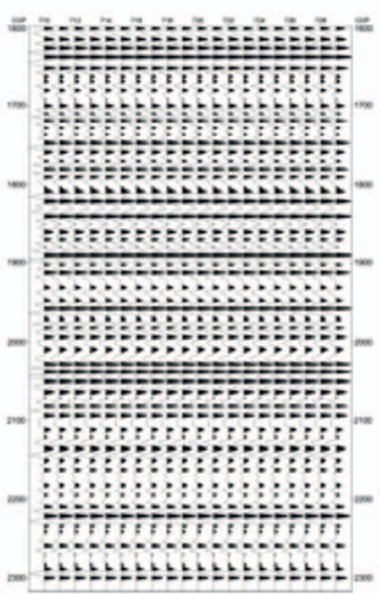

Sygnal symetryczny $70 \mathrm{~Hz}$ Okno: $1600-2300 \mathrm{~ms}$
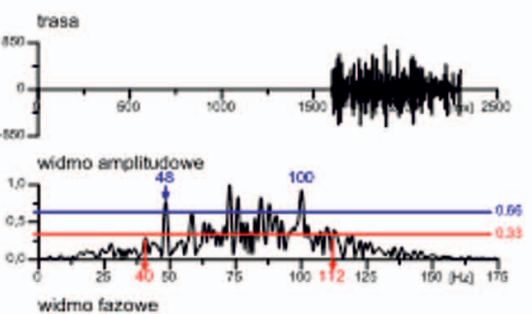

widma fazowe

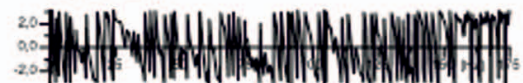

Rys. 15. Zróżnicowanie obrazu spektralnego dla różnych składowych fal sprężystych: (a) fala podłużna; (b) fala S, składowa transwersalna; (c) fala $\mathrm{S}$, składowa radialna

\section{Wykorzystanie modyfikacji spektralnej do identyfikacji refleksów fal poprzecznych i przemiennych na sekcjach fal podłużnych}

Potwierdzone wynikami analiz na modelach teoretycznych parametry modelu prędkościowo-głębokościowego posłużyły jako dane wejściowe do obliczania sekcji teoretycznych fal podłużnych, poprzecznych i konwertowanych [11, $15,20,21]$, dla których wykonano „pseudoakustyczną” inwersję sejsmiczną (rysunki 16a, b), stanowiącą cenny materiał dokumentujący efekty modyfikacji spektralnej. Przygotowane teoretyczne materiały do testowania możliwości poszerzenia zakresu interpretowalności sekcji fali podłużnej, poprzez wprowadzenie charakterystyki spektralnej pozyskanej z danych otworowych, porównano z wynikami na sekcjach rzeczywistych.

Na rysunku 17 przedstawiono wyniki inwersji sejsmicznej przeprowadzonej na jednej z sekcji rzeczywistych koncesji W (IL249), poddanej modyfikacji spektralnej. Uzyskane rozkłady prędkości dla fali podłużnej $(V p)$ w zakresie $2100 \div 5200 \mathrm{~m} / \mathrm{s}$ i dla fal poprzecznych $\left(V_{S x}, V_{s y}\right) \mathrm{w}$ zakre- sie $1850 \div 2100 \mathrm{~m} / \mathrm{s}$ dobrze odpowiadają wartościom odczytanym z profilowania prędkości (tablica 1) i pozytywnie weryfikują parametry modeli przedstawionych na rysunku 16.

Natomiast zakres częstotliwości wynikający z kształtu przyjętych do modelowania sygnałów elementarnych potwierdzony jest $\mathrm{w}$ drodze porównania sumarycznego sejsmogramu teoretycznego z krzywymi profilowania prędkości (rysunek 18), w interwałach czasu odpowiadających niektórym rejestrowanym horyzontom sejsmicznym $(\mathrm{Ca} 2, \mathrm{Sl}$, mlw_Reda strop, ....).

Przedstawione na rysunku 18 sejsmogramy dokumentują możliwość zaobserwowania fali poprzecznej na odbiornikach rejestrujących składową pionową fali podłużnej.

Przywołując logikę cytowanego schematu procedury modyfikacji spektralnej (rysunek 4) - są to działania z obszaru „niebieskiego". Uzyskane wyniki kontrolowane są rezultatami interpretacji markerów stratygraficznych (tablice 2-5). 

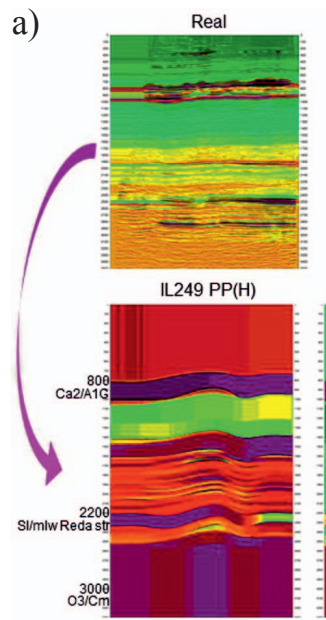

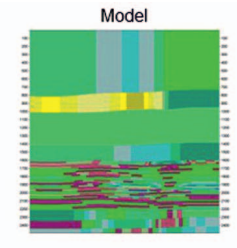

IL249 PS(H)

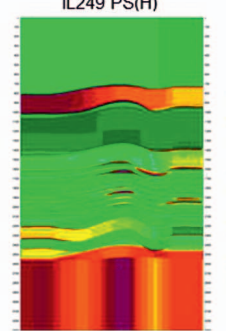

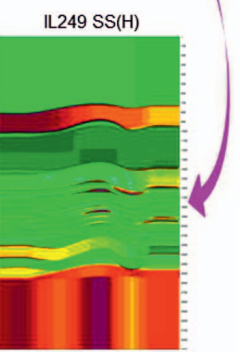

b)

IL249 PP

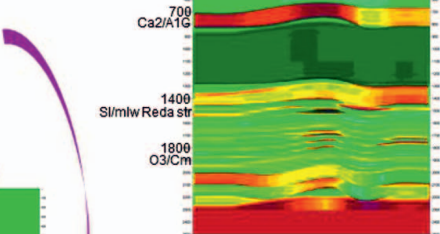

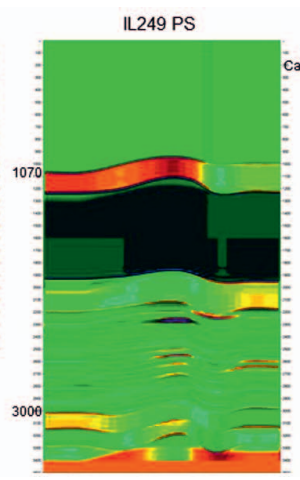

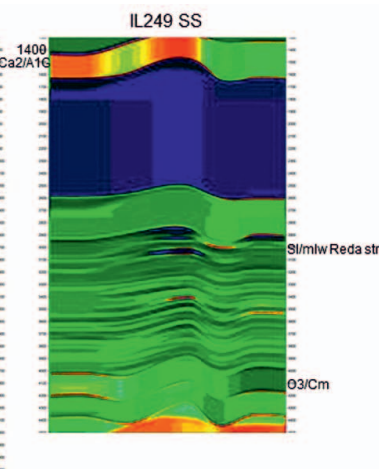

Rys. 16. Konstrukcja modeli prędkościowo-głębokościowych fali podłużnej i poprzecznej z wykorzystaniem relacji ilościowych (orientacyjne położenie markerów stratygraficznych): (a) sekcja rzeczywista i modele obliczone dla prędkości wyznaczonej w lokalizacji otworu L-1; (b) kontrolne sekcje czasowe impedancji dla fal podłużnych, konwertowanych i poprzecznych

V249OP1D V249OP4C VI249OP4

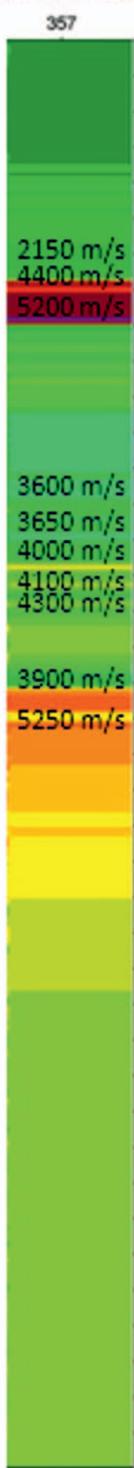

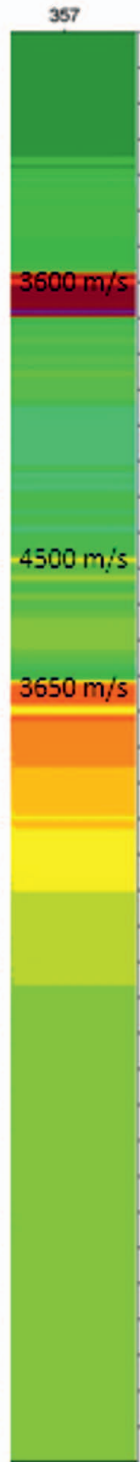

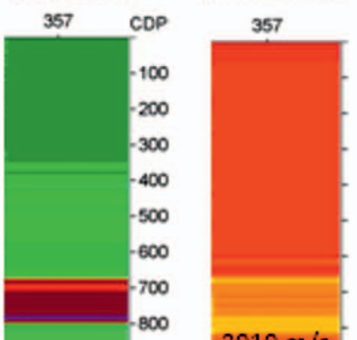

$2010 \mathrm{~m} / \mathrm{s}$

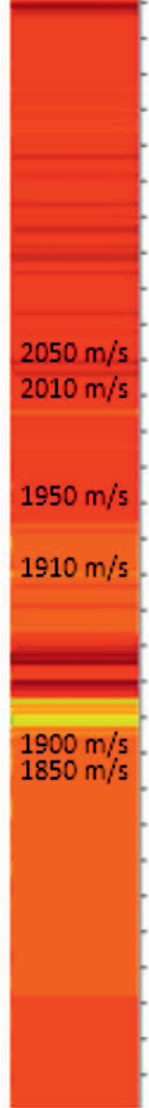

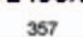
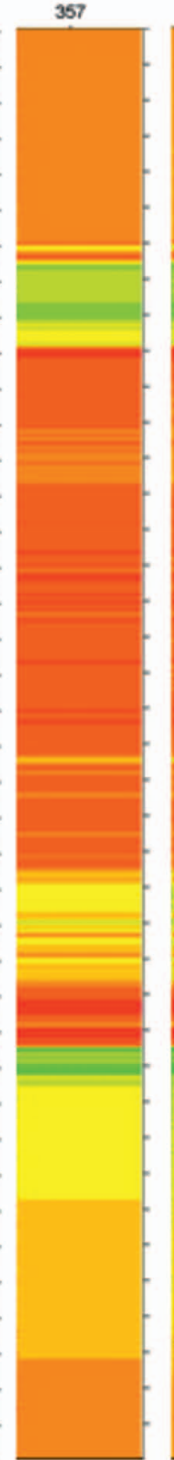

(3)
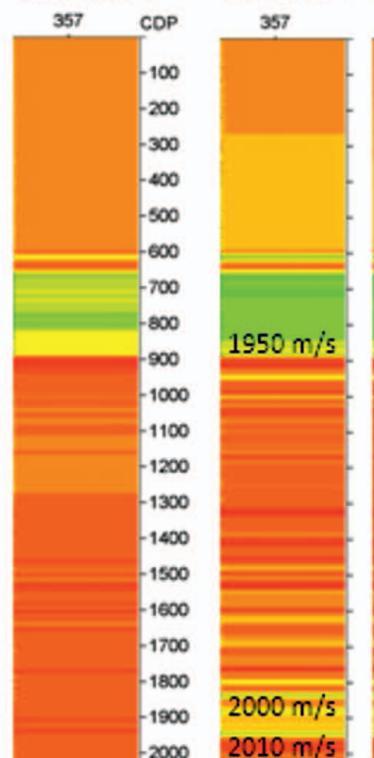

$2010 \mathrm{~m} / \mathrm{s}$.

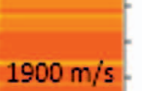

$1900 \mathrm{~m} / \mathrm{s}$

$1900 \mathrm{~m} / \mathrm{s}$
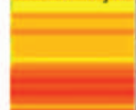

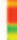

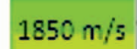

.

舟

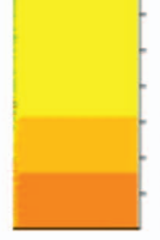

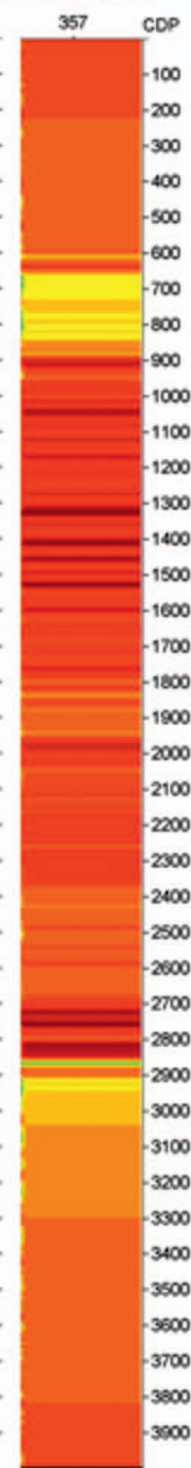

Rys. 17. Porównanie rozkładu prędkości otrzymanych w drodze inwersji rzeczywistych sekcji sejsmicznych oraz interpolowanych $\mathrm{z}$ danych otworowych 
Tablica 1. Porównanie prędkości propagacji fal podłużnych i poprzecznych Vpp, Vsy, Vsx [m/s] w skali głębokości MD [m] i czasu podwójnego 2T [ms] zarejestrowanych w otworze L-1

\begin{tabular}{|c|c|c|c|c|c|c|c|c|}
\hline $\begin{array}{c}\text { MD } \\
\text { głębokość } \\
{[\mathrm{m}]}\end{array}$ & $\begin{array}{c}2 \mathrm{~T}_{-} \mathrm{pp} \\
{[\mathrm{ms}]}\end{array}$ & $\begin{array}{c}V p p \\
{[\mathrm{~m} / \mathrm{s}]}\end{array}$ & $\begin{array}{c}\text { MD } \\
\text { głębokość } \\
{[\mathrm{m}]}\end{array}$ & $\begin{array}{c}2 \mathrm{~T}_{-} \mathrm{sy} \\
{[\mathrm{ms}]}\end{array}$ & $\begin{array}{c}V s y \\
{[\mathrm{~m} / \mathrm{s}]}\end{array}$ & $\begin{array}{c}\text { MD } \\
\text { głębokość } \\
{[\mathrm{m}]}\end{array}$ & $\begin{array}{c}2 T_{-} \mathrm{sx} \\
{[\mathrm{ms}]}\end{array}$ & $\begin{array}{c}V s x \\
{[\mathrm{~m} / \mathrm{s}]}\end{array}$ \\
\hline 580,281 & 564,17 & 2157,60 & & & & & & \\
\hline 584,281 & 567,45 & 2135,12 & & & & & & \\
\hline 588,281 & 570,65 & 2219,23 & & & & & & \\
\hline 592,281 & 573,80 & 2211,43 & & & & & & \\
\hline 596,281 & 576,94 & 2174,82 & & & & & & \\
\hline 600,281 & 580,09 & 2182,15 & & & & & & \\
\hline 604,281 & 583,29 & 2171,02 & & & & & & \\
\hline 608,281 & 586,50 & 2003,74 & & & & & & \\
\hline 612,281 & 589,74 & 2154,45 & & & & & & \\
\hline 616,281 & 593,03 & 2132,73 & & & & & & \\
\hline \multirow[t]{2}{*}{620,281} & 596,24 & 2355,11 & & & & & & \\
\hline & & 2345,42 & 768,01 & 791,13 & & & & \\
\hline 772,281 & 686,46 & 2551,37 & 772,01 & 795,56 & & & & \\
\hline 776,281 & 688,23 & 2809,67 & 776,01 & 799,98 & & & & \\
\hline 780,281 & 690,00 & 3950,59 & 780,01 & 804,39 & 1931,27 & & & \\
\hline 784,281 & 691,76 & 3953,62 & 784,01 & 808,83 & 2046,47 & & & \\
\hline 788,281 & 693,53 & 4547,04 & 788,01 & 813,26 & 2083,23 & 788,007 & 814,70 & 1976,07 \\
\hline 792,281 & 695,30 & 5095,41 & 792,01 & 817,71 & 1858,75 & 792,007 & 818,66 & 2042,54 \\
\hline 796,281 & 697,06 & 4897,49 & 796,01 & 822,14 & 1909,19 & 796,007 & 822,6 & 1953,45 \\
\hline 800,281 & 698,83 & 4463,54 & 800,01 & 826,59 & 1836,82 & 800,007 & 826,74 & 2014,03 \\
\hline 804,281 & 700,60 & 4869,01 & 804,01 & 831,04 & 1886,83 & 804,007 & 830,91 & 1852,95 \\
\hline 808,281 & 702,36 & 3893,71 & 808,01 & 835,45 & 1993,98 & 808,007 & 835,25 & 1915,17 \\
\hline 812,281 & 704,11 & 3293,48 & 812,01 & 839,81 & 1949,94 & 812,007 & 839,41 & 1930,83 \\
\hline 816,281 & 705,86 & 4203,15 & 816,01 & 844,15 & 1957,87 & 816,007 & 843,60 & 1969,51 \\
\hline 820,281 & 707,60 & 3264,11 & 820,01 & 848,45 & 1963,54 & 820,007 & 847,71 & 2089,09 \\
\hline 824,281 & 709,35 & 3513,93 & 824,01 & 852,81 & 1973,45 & 824,007 & 851,70 & 1970,04 \\
\hline 828,281 & 711,10 & 3358,09 & 828,01 & 857,17 & 2119,06 & 828,007 & 855,67 & 2023,02 \\
\hline 832,281 & 712,84 & 4022,74 & 832,01 & 861,51 & 2107,00 & 832,007 & 859,60 & 2058,37 \\
\hline 836,281 & 714,59 & 5187,04 & 836,01 & 865,85 & 1838,24 & 836,007 & 863,41 & 2061,08 \\
\hline 840,281 & 716,34 & 5936,12 & 840,01 & 870,19 & 1888,69 & 840,007 & 867,45 & 1917,53 \\
\hline 844,281 & 718,09 & 5344,18 & 844,01 & 874,53 & 1815,93 & 844,007 & 871,69 & 1899,91 \\
\hline 1800,281 & 1271,21 & 3529,27 & 1800,01 & 1821,12 & 1880,09 & 1800,007 & 1831,96 & 2059,60 \\
\hline 1804,281 & 1273,40 & 3580,15 & 1804,01 & 1825,02 & 2058,43 & 1804,007 & 1835,82 & 1984,80 \\
\hline 1808,281 & 1275,55 & 3568,62 & 1808,01 & 1828,92 & 1906,24 & 1808,007 & 1839,78 & 2140,82 \\
\hline 1812,281 & 1277,68 & 3470,32 & 1812,01 & 1832,89 & 1967,08 & 1812,007 & 1843,66 & 2072,57 \\
\hline 1816,281 & 1279,87 & 3609,15 & 1816,01 & 1837,03 & 1926,96 & 1816,007 & 1847,65 & 1979,99 \\
\hline 1820,281 & 1282,06 & 3631,19 & 1820,01 & 1841,22 & 2023,40 & 1820,007 & 1851,62 & 1972,24 \\
\hline 1824,281 & 1284,23 & 3618,47 & 1824,01 & 1845,28 & 1939,38 & 1824,007 & 1855,65 & 1962,90 \\
\hline 1828,281 & 1286,38 & 3546,46 & 1828,01 & 1849,32 & 1982,43 & 1828,007 & 1859,67 & 1967,54 \\
\hline 1832,281 & 1288,55 & 3538,02 & 1832,01 & 1853,45 & 2054,96 & 1832,007 & 1863,71 & 1965,41 \\
\hline 1836,281 & 1290,75 & 3554,46 & 1836,01 & 1857,51 & 2045,98 & 1836,007 & 1867,63 & 2004,30 \\
\hline 1840,281 & 1292,90 & 3583,29 & 1840,01 & 1861,57 & 2012,49 & 1840,007 & 1871,48 & 2057,23 \\
\hline 1844,281 & 1295,02 & 3541,20 & 1844,01 & 1865,52 & 1967,65 & 1844,007 & 1875,39 & 2073,90 \\
\hline 1848,281 & 1297,17 & 3485,96 & 1848,01 & 1869,39 & 1998,43 & 1848,007 & 1879,24 & 2054,69 \\
\hline 1852,281 & 1299,37 & 3675,67 & 1852,01 & 1873,25 & 1945,09 & 1852,007 & 1883,13 & 2035,96 \\
\hline 1856,281 & 1301,56 & 3424,97 & 1856,01 & 1877,08 & 2051,92 & 1856,007 & 1887,18 & 1994,04 \\
\hline 1860,281 & 1303,77 & 3581,72 & 1860,01 & 1880,97 & 1897,69 & 1860,007 & 1891,16 & 2054,59 \\
\hline 1864,281 & 1305,97 & 3770,11 & 1864,01 & 1884,96 & 2031,09 & 1864,007 & 1895,03 & 2077,43 \\
\hline 1868,281 & 1308,16 & 3699,22 & 1868,01 & 1889,06 & 1949,29 & 1868,007 & 1898,94 & 1985,20 \\
\hline 1872,281 & 1310,30 & 3728,52 & 1872,01 & 1893,04 & 1927,15 & 1872,007 & 1902,92 & 2030,60 \\
\hline 1876,281 & 1312,48 & 3513,44 & 1876,01 & 1896,92 & 1975,47 & 1876,007 & 1906,92 & 1957,67 \\
\hline 1880,281 & 1314,65 & 3639,85 & 1880,01 & 1900,94 & 1922,51 & 1880,007 & 1911,00 & 1998,98 \\
\hline 1884,281 & 1316,81 & 3675,78 & 1884,01 & 1905,19 & 1798,17 & 1884,007 & 1914,93 & 2074,60 \\
\hline 1888,281 & 1318,98 & 3626,04 & 1888,01 & 1909,42 & 1942,07 & 1888,007 & 1918,84 & 2031,89 \\
\hline 1892,281 & 1321,16 & 3649,71 & 1892,01 & 1913,59 & 2087,70 & 1892,007 & 1922,84 & 1999,98 \\
\hline 1896,281 & 1323,31 & 3659,22 & 1896,01 & 1917,65 & 1998,21 & 1896,007 & 1926,82 & 2020,25 \\
\hline
\end{tabular}




\begin{tabular}{|c|c|c|c|c|c|c|c|c|}
\hline $\begin{array}{c}\text { MD } \\
\text { głębokość } \\
{[\mathrm{m}]}\end{array}$ & $\begin{array}{c}2 \mathrm{~T}_{-} \mathrm{pp} \\
{[\mathrm{ms}]}\end{array}$ & $\begin{array}{c}V p p \\
{[\mathrm{~m} / \mathrm{s}]}\end{array}$ & $\begin{array}{c}\text { MD } \\
\text { głębokość } \\
{[\mathrm{m}]}\end{array}$ & $\begin{array}{c}2 \mathrm{~T}_{-} \mathrm{sy} \\
{[\mathrm{ms}]}\end{array}$ & $\begin{array}{c}V s y \\
{[\mathrm{~m} / \mathrm{s}]}\end{array}$ & $\begin{array}{c}\text { MD } \\
\text { głębokość } \\
{[\mathrm{m}]}\end{array}$ & $\begin{array}{c}2 T_{-} \mathrm{sx} \\
{[\mathrm{ms}]}\end{array}$ & $\begin{array}{c}V_{S x} \\
{[\mathrm{~m} / \mathrm{s}]}\end{array}$ \\
\hline 1900,281 & 1325,45 & 3741,19 & 1900,01 & 1921,77 & 1970,31 & 1900,007 & 1930,82 & 1983,02 \\
\hline 1904,281 & 1327,60 & 3699,80 & 1904,01 & 1925,86 & 2103,69 & 1904,007 & 1934,85 & 1966,91 \\
\hline 1908,281 & 1329,75 & 3722,50 & 1908,01 & 1929,90 & 2031,77 & 1908,007 & 1938,90 & 2007,82 \\
\hline 1912,281 & 1331,81 & 3679,09 & 1912,01 & 1933,96 & 1975,14 & 1912,007 & 1942,88 & 1946,65 \\
\hline 1916,281 & 1333,96 & 3673,34 & 1916,01 & 1937,90 & 1917,75 & 1916,007 & 1946,89 & 2009,25 \\
\hline 1920,281 & 1336,11 & 3665,97 & 1920,01 & 1942,05 & 1878,95 & 1920,007 & 1950,91 & 1981,64 \\
\hline 1924,281 & 1338,25 & 3717,97 & 1924,01 & 1946,41 & 2022,08 & 1924,007 & 1954,92 & 2007,42 \\
\hline 1928,281 & 1340,40 & 3747,33 & 1928,01 & 1950,70 & 1991,48 & 1928,007 & 1958,92 & 1976,83 \\
\hline 1932,281 & 1342,56 & 3647,89 & 1932,01 & 1954,91 & 1985,49 & 1932,007 & 1962,94 & 2008,66 \\
\hline 1936,281 & 1344,71 & 3615,02 & 1936,01 & 1959,10 & 1912,49 & 1936,007 & 1966,94 & 2001,96 \\
\hline 1940,281 & 1346,85 & 3712,46 & 1940,01 & 1963,17 & 1970,96 & 1940,007 & 1970,92 & 2067,32 \\
\hline 1944,281 & 1349,00 & 3759,61 & 1944,01 & 1967,31 & 2063,09 & 1944,007 & 1974,83 & 2006,39 \\
\hline 1948,281 & 1351,14 & 3747,68 & 1948,01 & 1971,39 & 2097,15 & 1948,007 & 1978,85 & 2006,03 \\
\hline 1952,281 & 1353,28 & 3647,53 & 1952,01 & 1975,50 & 2211,66 & 1952,007 & 1982,78 & 2023,31 \\
\hline 2200,281 & 1478,63 & 3942,07 & 2200,01 & 2231,40 & 1973,59 & 2200,007 & 2227,28 & 2002,57 \\
\hline 2204,281 & 1480,53 & 3963,74 & 2204,01 & 2235,62 & 1896,09 & 2204,007 & 2231,29 & 1960,68 \\
\hline 2208,281 & 1482,43 & 3876,87 & 2208,01 & 2239,81 & 1918,09 & 2208,007 & 2235,34 & 1988,38 \\
\hline 2212,281 & 1484,39 & 3829,02 & 2212,01 & 2243,97 & 1981,96 & 2212,007 & 2239,39 & 1927,58 \\
\hline 2216,281 & 1486,28 & 4039,38 & 2216,01 & 2248,09 & 2030,50 & 2216,007 & 2243,48 & 2000,31 \\
\hline 2220,281 & 1488,15 & 4688,05 & 2220,01 & 2252,31 & 1837,14 & 2220,007 & 2247,56 & 1971,11 \\
\hline 2224,281 & 1489,98 & 5065,90 & 2224,01 & 2256,50 & 1837,22 & 2224,007 & 2251,61 & 1875,30 \\
\hline 2228,281 & 1491,78 & 4777,53 & 2228,01 & 2260,69 & 1850,99 & 2228,007 & 2255,81 & 1889,25 \\
\hline 2232,281 & 1493,62 & 4580,84 & 2232,01 & 2264,80 & 1863,99 & 2232,007 & 2260,01 & 1901,78 \\
\hline 2236,281 & 1495,48 & 4336,96 & 2236,01 & 2268,98 & 1911,64 & 2236,007 & 2264,26 & 1900,82 \\
\hline 2240,281 & 1497,37 & 4077,21 & 2240,01 & 2273,15 & 1886,76 & 2240,007 & 2268,54 & 1870,32 \\
\hline 2244,281 & 1499,25 & 4040,54 & 2244,01 & 2277,33 & 1913,91 & 2244,007 & 2272,75 & 1934,28 \\
\hline 2248,281 & 1501,13 & 4096,32 & 2248,01 & 2281,51 & 1916,28 & 2248,007 & 2276,86 & 1916,47 \\
\hline 2252,281 & 1502,99 & 4099,54 & 2252,01 & 2285,60 & 1890,63 & 2252,007 & 2280,97 & 1915,77 \\
\hline 2256,281 & 1504,91 & 4081,83 & 2256,01 & 2289,71 & 1937,20 & 2256,007 & 2285,09 & 1935,65 \\
\hline 2260,281 & 1506,89 & 4054,55 & 2260,01 & 2293,73 & 1958,41 & 2260,007 & 2289,18 & 1959,99 \\
\hline 2264,281 & 1508,82 & 4114,50 & 2264,01 & 2297,88 & 1878,48 & 2264,007 & 2293,25 & 1963,64 \\
\hline 2268,281 & 1510,70 & 4112,69 & 2268,01 & 2301,95 & 1930,36 & 2268,007 & 2297,33 & 1922,87 \\
\hline 2272,281 & 1512,62 & 4065,25 & 2272,01 & 2306,05 & 1903,13 & 2272,007 & 2301,48 & 1937,95 \\
\hline 2276,281 & 1514,58 & 4006,00 & 2276,01 & 2310,12 & 1903,38 & 2276,007 & 2305,62 & 1877,51 \\
\hline 2280,281 & 1516,48 & 4191,39 & 2280,01 & 2314,27 & 1936,15 & 2280,007 & 2309,75 & 1859,23 \\
\hline 2284,281 & 1518,40 & 4332,33 & 2284,01 & 2318,43 & 1919,93 & 2284,007 & 2313,88 & 1995,28 \\
\hline 2288,281 & 1520,31 & 4307,14 & 2288,01 & 2322,63 & 1898,24 & 2288,007 & 2317,96 & 1986,93 \\
\hline 2292,281 & 1522,25 & 3937,93 & 2292,01 & 2326,77 & 1964,44 & 2292,007 & 2322,05 & 1936,07 \\
\hline 2296,281 & 1524,26 & 4242,81 & 2296,01 & 2330,83 & 2011,95 & 2296,007 & 2326,17 & 1947,66 \\
\hline 2300,281 & 1526,26 & 4231,78 & 2300,01 & 2334,92 & 1884,70 & 2300,007 & 2330,23 & 1956,68 \\
\hline 2428,281 & 1587,17 & 4677,56 & 2428,01 & 2469,53 & 1865,11 & 2428,007 & 2462,13 & 1915,32 \\
\hline 2432,281 & 1589,06 & 4592,65 & 2432,01 & 2473,81 & 1838,77 & 2432,007 & 2466,27 & 1851,59 \\
\hline 2436,281 & 1590,95 & 4382,04 & 2436,01 & 2478,13 & 1808,03 & 2436,007 & 2470,62 & 1863,45 \\
\hline 2440,281 & 1592,83 & 4333,31 & 2440,01 & 2482,46 & 1886,05 & 2440,007 & 2474,79 & 1914,48 \\
\hline 2444,281 & 1594,71 & 4120,69 & 2444,01 & 2486,89 & 2010,21 & 2444,007 & 2479,13 & 1904,82 \\
\hline 2448,281 & 1596,59 & 4239,07 & 2448,01 & 2491,38 & 1929,59 & 2448,007 & 2483,30 & 1932,58 \\
\hline 2452,281 & 1598,45 & 4301,06 & 2452,01 & 2495,89 & 1948,24 & 2452,007 & 2487,39 & 1853,65 \\
\hline 2456,281 & 1600,29 & 4269,34 & 2456,01 & 2500,34 & 1901,40 & 2456,007 & 2491,59 & 1922,08 \\
\hline 2460,281 & 1602,13 & 4173,64 & 2460,01 & 2504,86 & 1934,72 & 2460,007 & 2495,75 & 1907,34 \\
\hline 2868,281 & 1790,35 & 4010,56 & 2868,01 & 2961,23 & 1800,10 & 2868,007 & 2945,10 & 1982,89 \\
\hline 2872,281 & 1792,30 & 4098,90 & 2872,01 & 2966,15 & 1899,90 & 2872,007 & 2949,14 & 1953,72 \\
\hline 2876,281 & 1794,07 & 3898,87 & 2876,01 & 2971,56 & 1915,80 & 2876,007 & 2953,23 & 1948,18 \\
\hline 2880,281 & 1795,53 & 3904,15 & 2880,01 & 2976,79 & 1997,74 & 2880,007 & 2957,29 & 1889,37 \\
\hline 2884,281 & 1797,04 & 4027,14 & 2884,01 & 2982,20 & 1956,41 & 2884,007 & 2961,36 & 1972,55 \\
\hline 2888,281 & 1798,58 & 3850,69 & 2888,01 & 2987,34 & 1925,11 & 2888,007 & 2965,39 & 1946,62 \\
\hline 2892,281 & 1800,17 & 3493,17 & 2892,01 & 2992,12 & 1805,20 & 2892,007 & 2969,48 & 2004,52 \\
\hline 2896,281 & 1801,71 & 3607,95 & 2896,01 & 2996,89 & 1864,08 & 2896,007 & 2973,66 & 1846,33 \\
\hline
\end{tabular}


Kolejność markerów stratygraficznych interpretowanych na krzywych otworowych i uwzględnionych w modelowaniu kolejnych okien sejsmogramów teoretycznych fal PP, SX i SY przedstawiono w tablicach 2, 3 i 4 .

Markery stratygraficzne zestawione wedug czasu i głębokości w tablicach 2, 3 i 4 ułatwiają lokalizację horyzontów na rysunku 18.

Dokumentowane możliwości odtworzenia parametrów fali poprzecznej z rejestracji fali podłużnej prezentują rysunki 19 i 20. Na rysunku 19 przedstawiono sekcję czasową (profil IL249) fali podłużnej, w przedziale czasowym odpowiadającym relacji krzywych prędkość-głębokość zarejestrowanych w otworze.

Dla fali podłużnej czas podwójny końca rejestracji krzywej prędkości wynosi około 1900 ms, zaś dla fal poprzecznych około 3150 ms (co odpowiada głębokości 2950 m).
Przekonującym dowodem możliwości optymalizacji interpretacji geofizyczno-geologicznej z wykorzystaniem modyfikacji spektralnej danych sejsmicznych jest rysunek 20 . Rozdzielenie cienkowarstwowych przeławiceń w interwale spągu syluru i stropu ordowiku stanowić może wskazówkę dotyczącą rozkładu współczynników o bardzo niewielkiej refleksyjności. Porównanie obrazu falowego, na którym zaaplikowano poszerzenie charakterystyki spektralnej, wskazuje na wagę parametrów procedury w odniesieniu do lokalizacji celu geologicznego. Zwiększenie szerokości widma o 4 oct skutkować może, jak widać, utratą czytelności horyzontów w interwale czasowym powyżej $1000 \mathrm{~ms}$ (w którym wysokie częstotliwości nie są wytłumione), natomiast zwiększeniem czytelności i rozdzielczości horyzontów w interwale czasów większych (>2000 ms). Obserwację powyższą potwierdzają parametry spektrum (rysunek 20c).

Tablica 2. Pozycje markerów stratygraficznych (według danych w otworze) odtworzone na sejsmogramach teoretycznych fali PP

\begin{tabular}{|c|c|c|l|}
\hline $\begin{array}{c}\text { Głębokość_SSTVD } \\
\text { okno }[\mathrm{m}]\end{array}$ & $\begin{array}{c}\text { Czas_TWT } \\
\text { okno }[\mathrm{m} / \mathrm{s}]\end{array}$ & Interwały & \multicolumn{1}{|c|}{ Markery } \\
\hline $300 \div 500$ & $325 \div 506$ & jura-trias & J, Tp3, T, Tp2 \\
\hline $650 \div 850$ & $634 \div 736$ & cechsztyn & Z3, P, Z2, A1G, Z1, Na1 \\
\hline $850 \div 1050$ & $736 \div 842$ & sylur_strop & A1D, Ca1+il, S3, S \\
\hline $1500 \div 1700$ & $1122 \div 1242$ & sylur & Sl \\
\hline $2000 \div 2200$ & $1410 \div 1513$ & sylur & mlw_Reda_strop \\
\hline $2300 \div 2500$ & $1562 \div 1660$ & sylur & il_Pelplin_strop \\
\hline $2750 \div 2950$ & $1774 \div 1852$ & sylur/kambr & $\begin{array}{l}\text { il_Pasłęk_strop, il_Jantar_strop, il_Sasino_strop, wap_Kopalino_strop, } \\
\text { il_Stuchowo_strop, Cm, Cm2 }\end{array}$ \\
\hline
\end{tabular}

Tablica 3. Pozycje markerów stratygraficznych (według danych w otworze) odtworzone na sejsmogramach teoretycznych fali SX

\begin{tabular}{|c|c|c|c|}
\hline $\begin{array}{l}\text { Głębokość_SSTVD } \\
\text { okno [m] }\end{array}$ & $\begin{array}{l}\text { Czas_TWT } \\
\text { okno }[\mathrm{m} / \mathrm{s}]\end{array}$ & Interwały & Markery \\
\hline $650 \div 800$ & $800 \div 933$ & cechsztyn & Z3, P, Z2, A1G, Z1, Na1 \\
\hline $900 \div 1000$ & $1043 \div 1144$ & cechsztyn/sylur & $\mathrm{A} 1 \mathrm{D}, \mathrm{Ca} 1+\mathrm{il}, \mathrm{S} 3, \mathrm{~S}$ \\
\hline $1500 \div 1600$ & $1637 \div 1735$ & sylur & S1 \\
\hline $1700 \div 1900$ & $1832 \div 2031$ & sylur & \\
\hline $2100 \div 2260$ & $2228 \div 2393$ & sylur & mlw_Reda_strop \\
\hline $2700 \div 2950$ & $2873 \div 3153$ & sylur/kambr & $\begin{array}{l}\text { il_Pasłęk_strop, il_Jantar_strop, il_Sasino_strop, wap_Kopalino_strop, } \\
\text { il_Słuchowo_strop, Cm, Cm } 2\end{array}$ \\
\hline
\end{tabular}

Tablica 4. Pozycje markerów stratygraficznych (według danych w otworze) odtworzone na sejsmogramach teoretycznych fali SY

\begin{tabular}{|c|c|c|c|}
\hline $\begin{array}{l}\text { Głębokość_SSTVD } \\
\text { okno }[\mathrm{m}]\end{array}$ & $\begin{array}{l}\text { Czas_TWT } \\
\text { okno }[\mathrm{m} / \mathrm{s}]\end{array}$ & Interwały & Markery \\
\hline $650 \div 780$ & $800 \div 915$ & cechsztyn & Z3, P, Z2, A1G, Z1, Na1 \\
\hline $900 \div 1000$ & $1038 \div 1136$ & cechsztyn/sylur & A1D, Ca1+il, S3, S \\
\hline $1500 \div 1600$ & $1621 \div 1720$ & sylur & $\mathrm{S} 1$ \\
\hline $1700 \div 1900$ & $1822 \div 2027$ & sylur & \\
\hline $2100 \div 2260$ & $2232 \div 2335$ & sylur & mlw_Reda_strop \\
\hline $2700 \div 2950$ & $2887 \div 3194$ & sylur/kambr & $\begin{array}{l}\text { il_Pasłęk_strop, il_Jantar_strop, il_Sasino_strop, wap_Kopalino_strop, } \\
\text { il_Stuchowo_strop, Cm, Cm2 }\end{array}$ \\
\hline
\end{tabular}



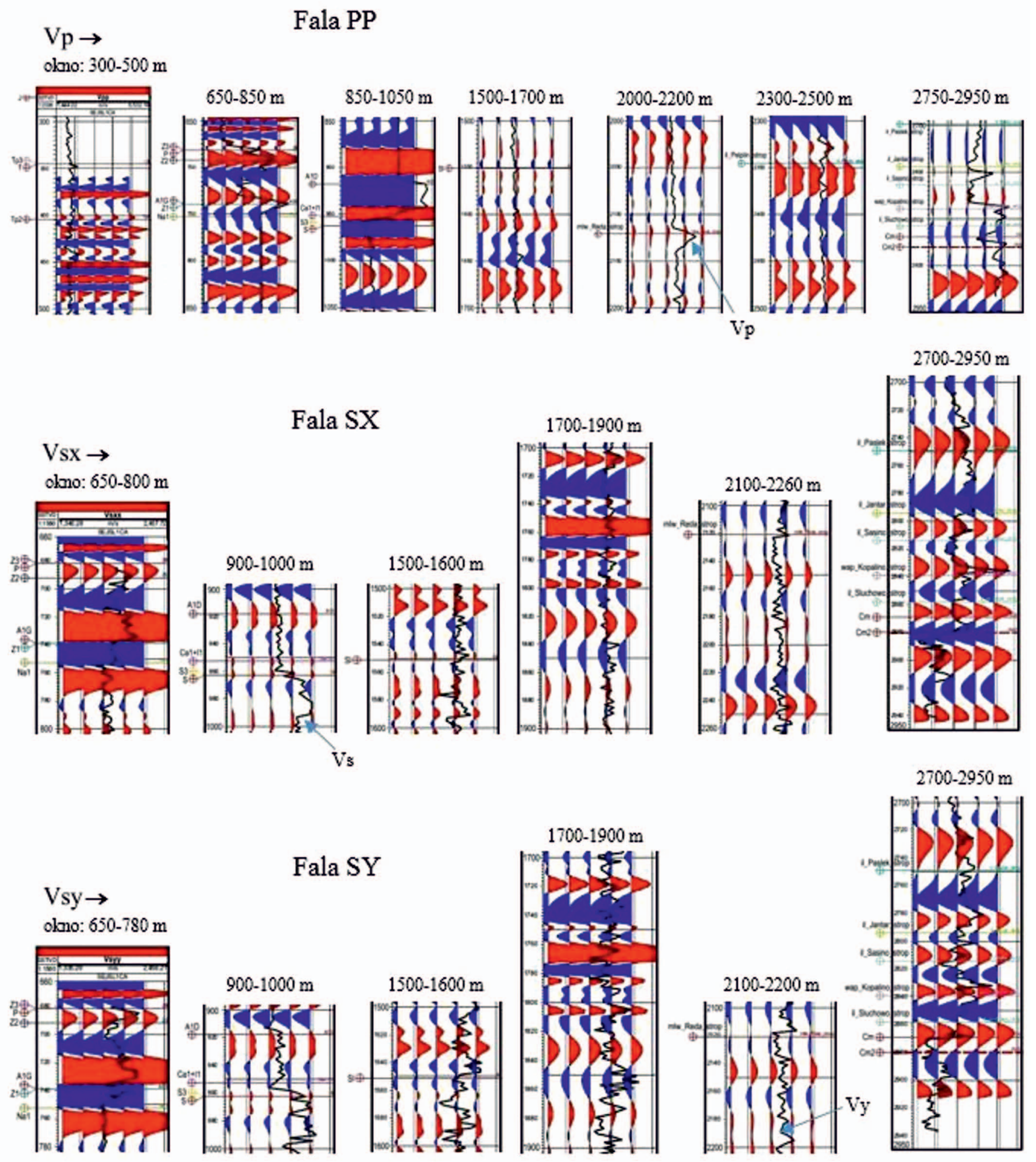

Rys. 18. Krzywe otworowe $V p, V s x$ i $V s y$ oraz sejsmogramy teoretyczne w wybranych oknach sekwencji czasowej

Wymienione obliczenia odpowiadają opcji 1 procedury modyfikacji i realizowane są w obszarze ,pomarańczowym” schematu (rysunek 4).

Przytoczone rozważania mają charakter metodyczny; celem jest pokazanie nowych możliwości interpretacyjnych wynikających z wykorzystania modyfikacji zespolonej charakterystyki spektralnej. Porównanie rozdzielczości sekcji sejsmicznej wejściowej i po modyfikacji spektralnej jednoznacznie wskazuje znacznie większą różnorodność szczegółów budowy geologicznej, którą możemy wydzielić na sekcji o szerszym zakresie częstotliwości (rysunek 21).

Analogiczna uwaga dotyczy sekcji sejsmicznej po wykonaniu transformacji czasowo-głębokościowej. Porównanie danych profilowania prędkości w otworze oraz wyników 


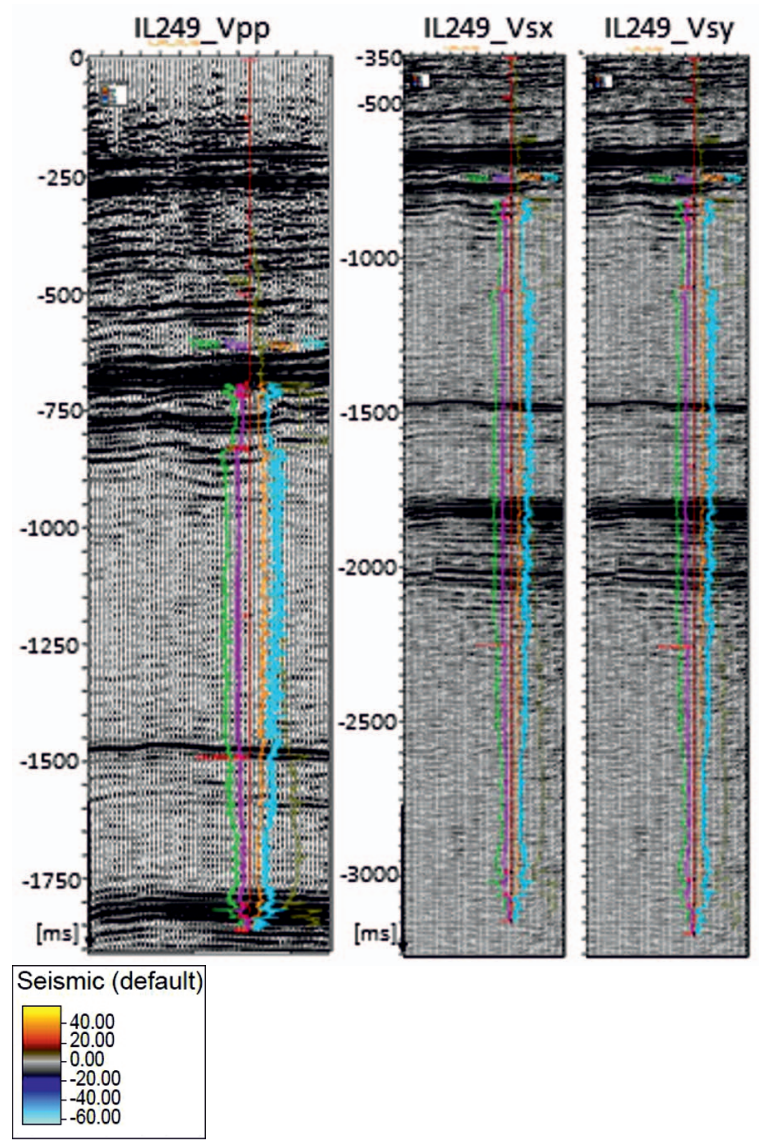

Rys. 19. Zarejestrowane pole sejsmiczne z wprowadzonymi informacjami z danych otworowych (prędkości fali P i S)

Tablica 5. Markery i czasy poziomów stratygraficznych dla fali P i S

\begin{tabular}{|c|c|c|c|c|}
\hline \multirow{2}{*}{$\begin{array}{c}\text { Markery } \\
\text { stratygraficzne }\end{array}$} & \multirow{2}{*}{$\begin{array}{c}\text { Fala PP } \\
\text { Czas } \\
{[\mathrm{ms}]}\end{array}$} & \multirow{2}{*}{$\begin{array}{c}\text { Markery } \\
\text { stratygraficzne }\end{array}$} & \multicolumn{2}{|c|}{ Fala S } \\
\hline & & & $\begin{array}{l}\text { Czas }[\mathrm{ms}] \\
V s x=V s x x\end{array}$ & $\begin{array}{l}\text { Czas [ms] } \\
V s y=V_{s y y}\end{array}$ \\
\hline $\mathrm{J}$ & 335 & $\mathrm{P}$ & 808 & 808 \\
\hline $\mathrm{T}$ & 445 & $\mathrm{Ca} 2$ & 825 & 825 \\
\hline Tp2 & 500 & $\mathrm{~A} 1 \mathrm{G}$ & 868 & - \\
\hline $\mathrm{P}$ & 690 & Cal & 1100 & - \\
\hline $\mathrm{Ca} 2$ & 698 & $\mathrm{~S}$ & 1108 & 1100 \\
\hline $\mathrm{S}$ & 834 & SI & 1688 & 1672 \\
\hline SI & 1188 & mlw Reda_strop & 2250 & 2255 \\
\hline mlw Reda_strop & 1490 & $\mathrm{O} 3$ & 2986 & 3010 \\
\hline $\mathrm{O} 3$ & 1805 & $\mathrm{Cm}$ & 3053 & 3090 \\
\hline $\mathrm{Cm}$ & 1830 & END & 3143 & 3185 \\
\hline END & 1860 & & & \\
\hline
\end{tabular}

inwersji sejsmicznej (rysunek 22) wskazuje na pozytywne rokowania omawianej metodyki.

Koincydencja szczegółów na obrazie sejsmicznym oraz widocznych na krzywej prędkości zarejestrowanej w otworze jest bardzo wysoka.
Zachęcające wyniki zwiększenia rozdzielczości z wykorzystaniem operatorów modyfikacji spektralnej obliczonych z udziałem krzywej refleksyjności fali podłużnej spowodowały rozpoczęcie testowania skuteczności operatorów obliczanych z udziałem krzywych refleksyjności fali poprzecznej SX i SY, co przedstawiono jako opcję 2 w obszarze ,pomarańczowym" schematu procedury (rysunek 4). Wyniki obliczeń analiz spektralnych zaprezentowano na rysunkach 8 i 9, a rezultaty w postaci finalnych sekcji sejsmicznych na rysunkach 23 i 24. Ocenę stopnia zgodności wyników sejsmicznych i geologicznych ułatwiają tablice 2, 3, 4 i 5, w których wskazano czasy ewentualnego występowania refleksów fali poprzecznej, a identyfikowanych na polu falowym fali podłużnej.

Celem powyższego eksperymentu było stwierdzenie możliwej obecności refleksów fali poprzecznej (składowych poziomych) na sekcji sejsmicznej PP, rejestrowanych ponadto odbiornikami przeznaczonymi do rejestracji składowej pionowej. Dokonanie modyfikacji charakterystyki spektralnej fali podłużnej za pomocą operatora obliczonego z udziałem funkcji refleksyjności fali P pokazuje, że interwały czasowe na rejestracjach standardowych fal podłużnych (PSTM), uznawane za interwały bezrefleksowe, zapełniają się informacjami. Słabe refleksy pojawiają się na czasach odpowiadających rejestracjom fali poprzecznej (w wersji amplitudowej - rysunek 23 i wersji impedancji - rysunek 24). Wynik ten należy uznać za ważny.

Horyzont Reda_strop pojawia się na wszystkich trzech składowych, ale zdecydowanie najsilniej na składowej transwersalnej, prawie prostopadle do blisko południkowego kierunku przebiegu profilu IL249. Identyczna informacja wynika z obrazu inwersji sejsmicznej.

Przedstawione na rysunkach 23 i 24 sekcje amplitudowe i po inwersji sejsmicznej potwierdzają możliwości nowej metodyki. Jednak należy podkreślić, że poprawność rozwiązania nie determinuje bezwzględnych i natychmiastowych sukcesów $\mathrm{w}$ interpretacji nowych materiałów.

$\mathrm{Na}$ rysunku 25 zaprezentowano rezultaty modyfikacji spektralnej fali poprzecznej (składowa transwersalna i radialna) wynikające $\mathrm{z}$ aplikowania nieco różnych operatorów modyfikacji (wersja O i T). Najlepszą zgodność krzywej otworowej oraz pola prędkości odnotowuje się w przypadku opcji SXT_Vsx.

Powyższe spostrzeżenia mogą mieć ogromną wagę, szczególnie przy ocenie niejednorodności ośrodka, niekiedy - nie zawsze właściwie - traktowanej jako anizotropia. Daje to okazję do uwzględnienia głębokości analizowanych warstw, 


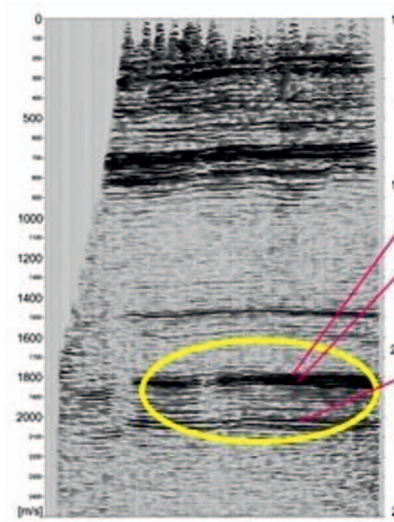

(a)

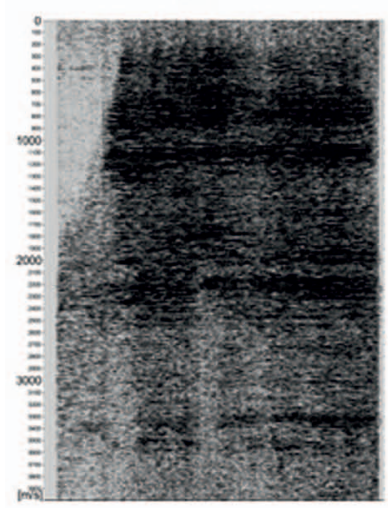

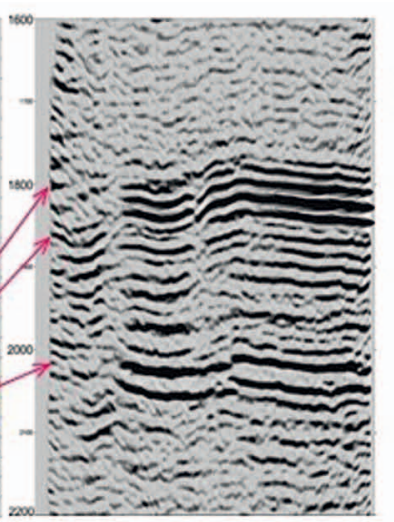

(b)

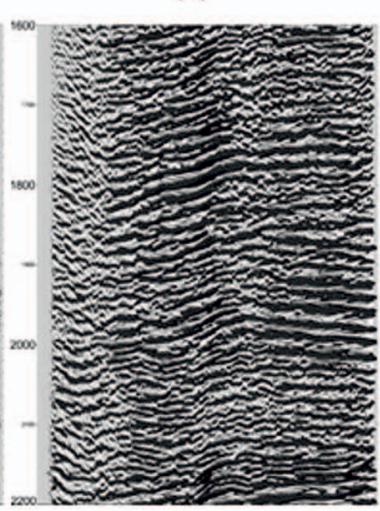

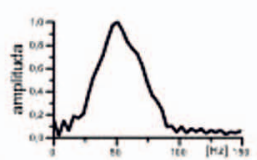
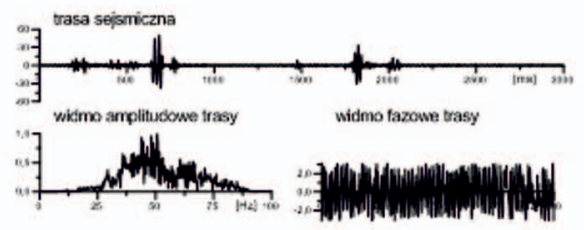

(c)

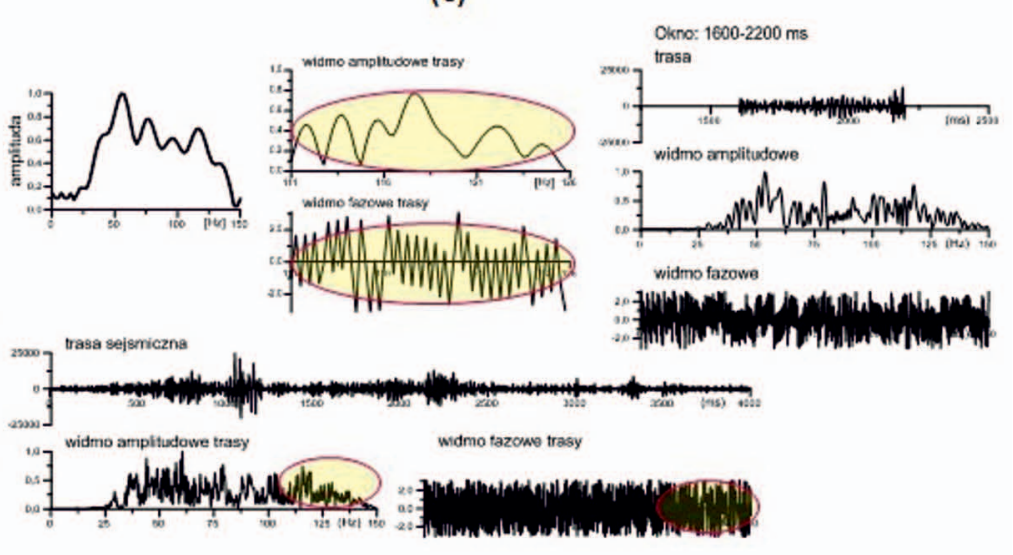

Rys. 20. Analizowana sekcja sejsmiczna (a) i wybrany interwał czasowy (2T: 1600 $\div 2200 \mathrm{~ms}$ ) odpowiadający celowi poszukiwań geologicznych (b) oraz odpowiadające im charakterystyki spektralne (c)

Sekcja sejsmiczna INPUT

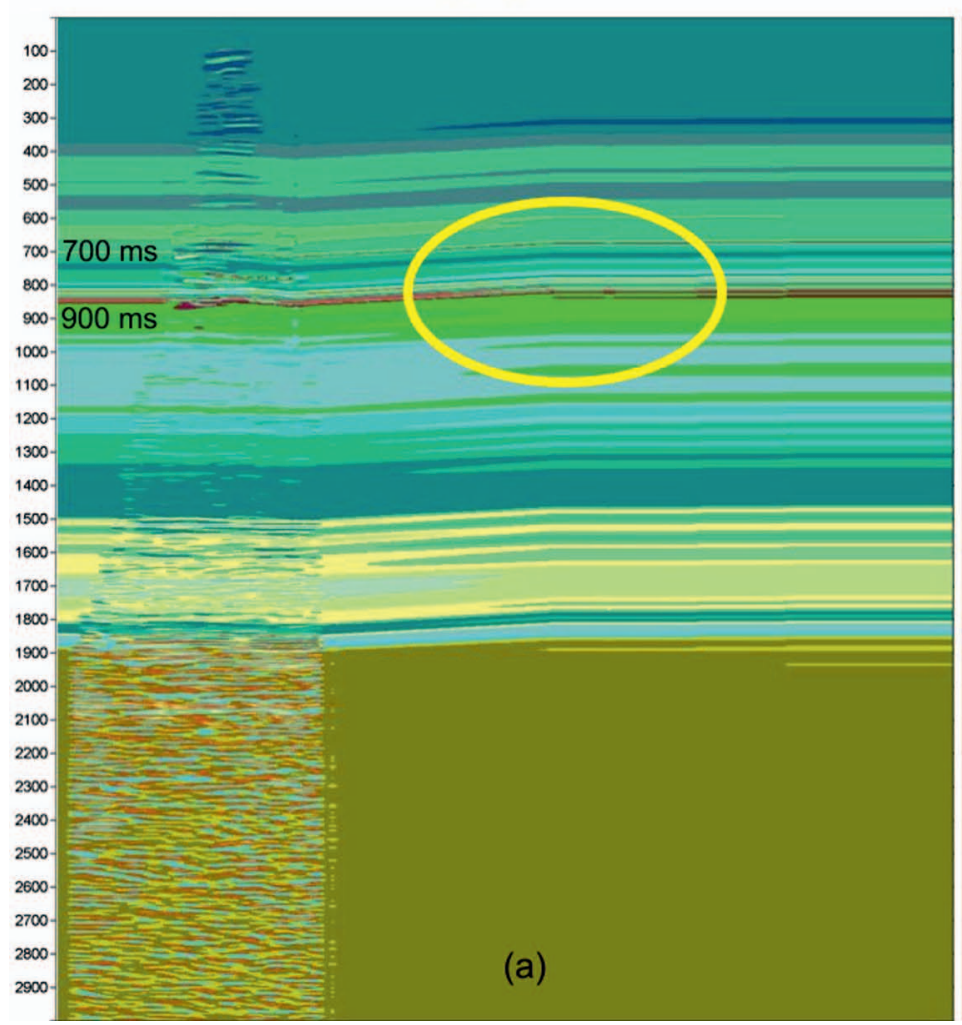

Sekcja INPUT po modyfikacji spektralnej

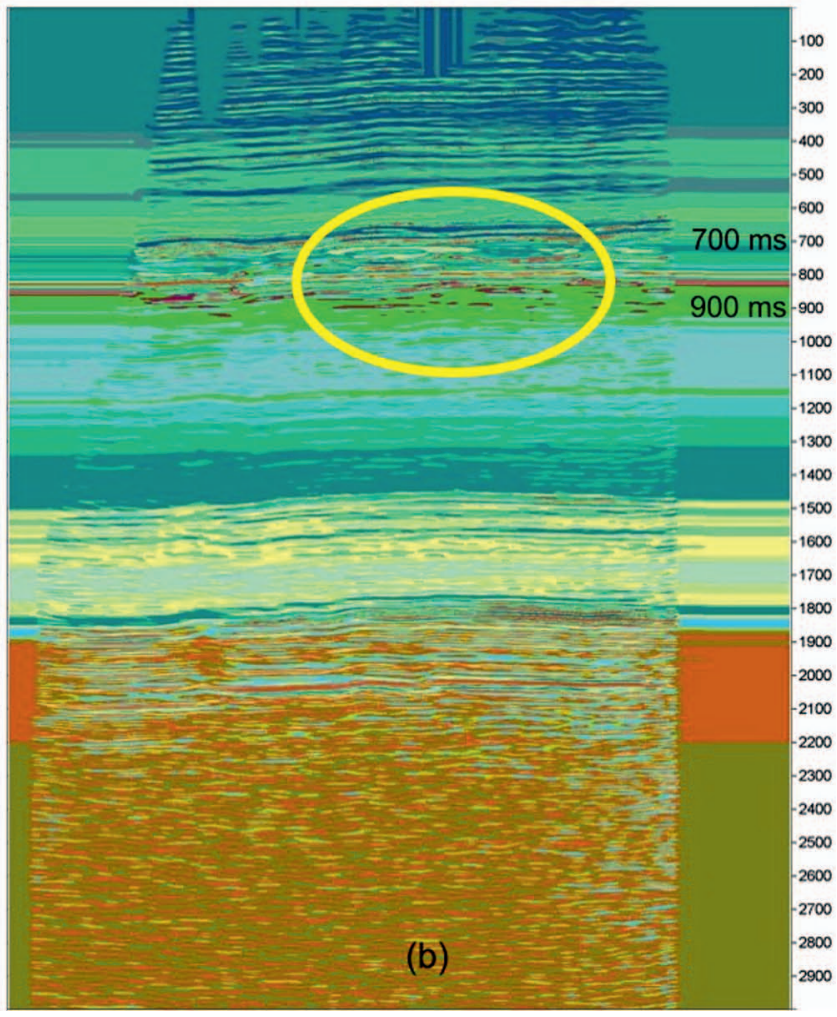

Rys. 21. Porównanie rozdzielczości sekcji czasowej impedancji w opcji podstawowej (a) i w opcji po zwiększeniu zakresu częstotliwości (b) 


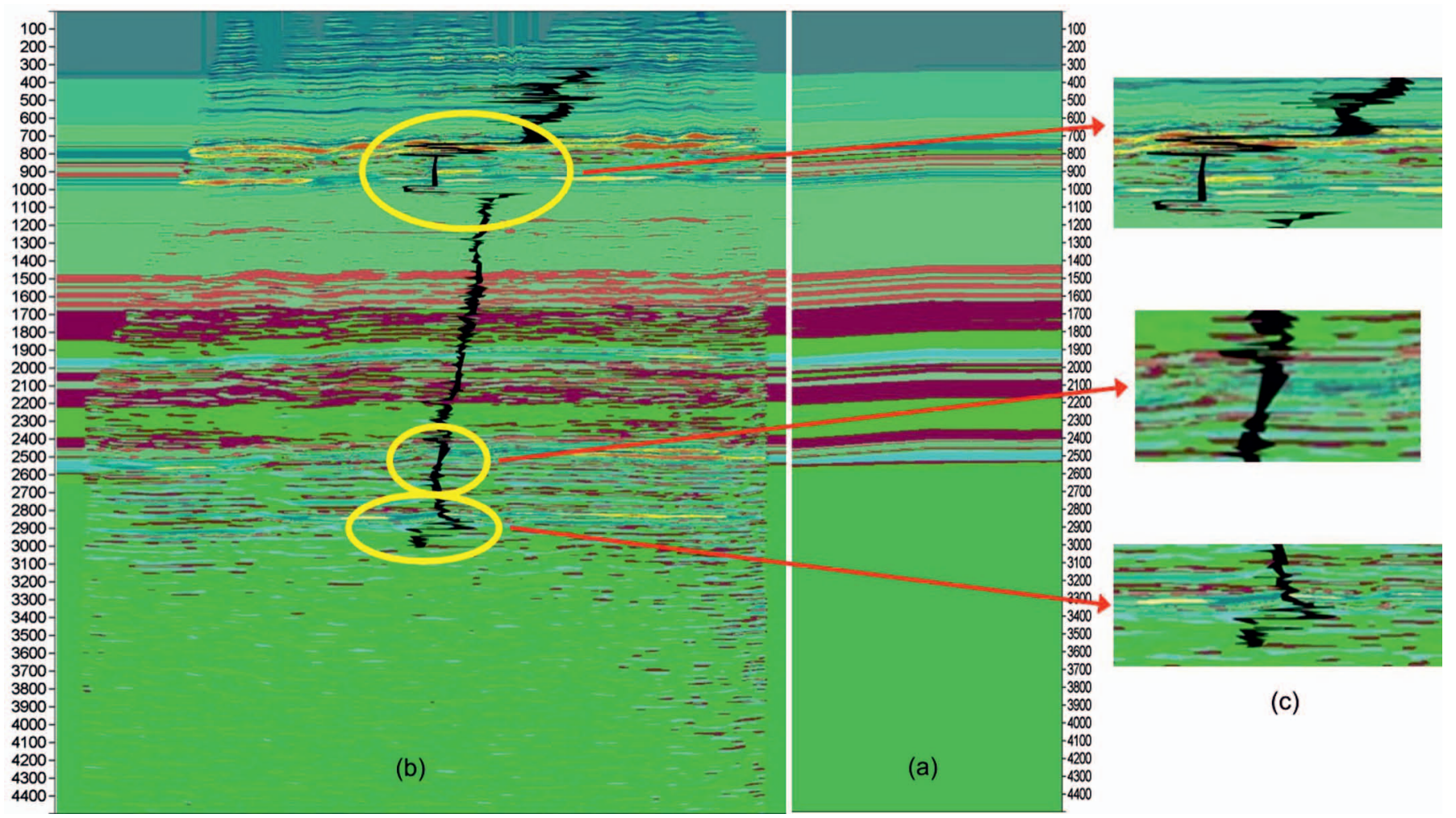

Rys. 22. Porównanie wyników inwersji sejsmicznej po transformacji czasowo-głębokościowej w wersji podstawowej (a) i po modyfikacji spektralnej (b). Wersja powiększona (c)

parametrów akwizycji oraz zmienności badanego parametru fizycznego w odniesieniu do przestrzennego gradientu tej zmienności. Pokazane wyżej, na rysunku 9, widma amplitudowe po modyfikacji spektralnej potwierdzają możliwość rekonstrukcji zakresu częstotliwościowego spektrum sekcji sejsmicznej w stosunku do spektrum danych otworowych (rysunki 5 i 6 ).

Budowa i specyfika obiektów geologicznych przekłada się na parametry i procedury przetwarzania oraz na ,wnioskowanie geologiczne". Ten właśnie aspekt pokazano na rysunku 25, na którym przedstawiono różne wyniki modyfikacji pola (O i T) przy niewielkiej zmianie operatora. Sugerują one, iż istnieją szerokie możliwości doboru parametrów operatora modyfikacji, które umożliwią bardziej prawidłowe odtworzenie budowy ośrodka geologicznego. Ocena prawidłowości tego odtworzenia często nie jest łatwa do przeprowadzenia. Oczywiście zależy to od liczby odwiertów w rejonie badań, jak też od wielości założeń metodycznych projektu, a więc od możliwości konfrontacji wyników na platformie interdyscyplinarnej.

W omawianym przypadku dominacja zapisu sejsmicznego na składowej transwersalnej SX fali poprzecznej wydaje się potwierdzona przez jeden z wyników modelowań geolo- gicznych, przedstawiony na rysunku 26 [25]. Pokazany fragment mapy nasyceń $S w$ (ang. water saturation), usytuowany w pobliżu wykorzystywanego w obliczeniach odwiertu L-1, charakteryzuje się obrazem wyraźnej anomalii podwyższonego nasycenia $S w$ o wartościach rzędu $0,85 \div 0,95$ i zaznaczonym trendzie SWW-NEE. Kierunek ten jest jednocześnie charakterystyczny dla układu właściwości ośrodka wynikających z odrębnej reakcji propagującej fali poprzecznej na niejednorodności budowy, a szczególnie na obecność płynów.

Na zapisie sejsmicznym fali podłużnej poddanej uprzednio modyfikacji spektralnej z zastosowaniem operatorów obliczonych z funkcji refleksyjności składowych SX i SY zarejestrowanych w otworze (rysunki 23, 24, 25) - obserwuje się znacznie wyraźniejsze ciągi amplitud refleksów oraz wyróżniające wartości impedancji właśnie na sekcjach w opcji składowej transwersalnej (SXO, SXT). Jest to kierunek prostopadły do południkowego przebiegu profilu IL249, na którym w interwale sylurskim $1600 \div 1950 \mathrm{~ms}$ prowadzono analizy i testowanie opracowanych procedur.

Nie sposób pominąć uwagi o korelacji dwóch trendów: obserwowanych na mapie nasyceń (rysunek 26) oraz wynikających z wprowadzenia charakterystyki spektralnej składowej transwersalnej fali poprzecznej. 


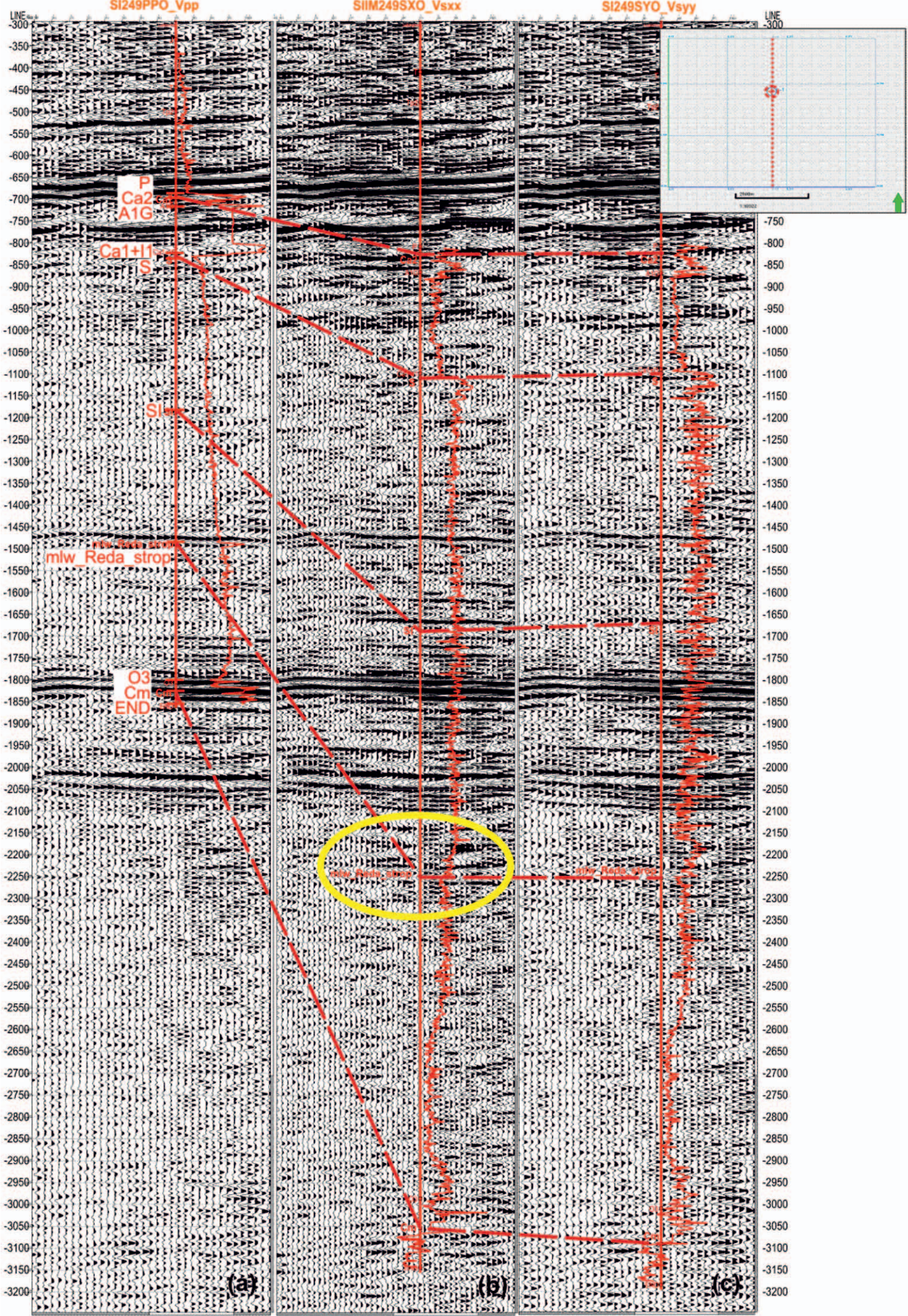

Rys. 23. Sekcje sejsmiczne po zastosowaniu różnych opcji modyfikacji spektralnej: (a) uwzględnienie spektrum fal podłużnych (składowa pionowa - Z); (b) uwzględnienie spektrum fal poprzecznych (składowa transwersalna - SX); (c) uwzględnienie spektrum fal poprzecznych (składowa radialna - SY) 


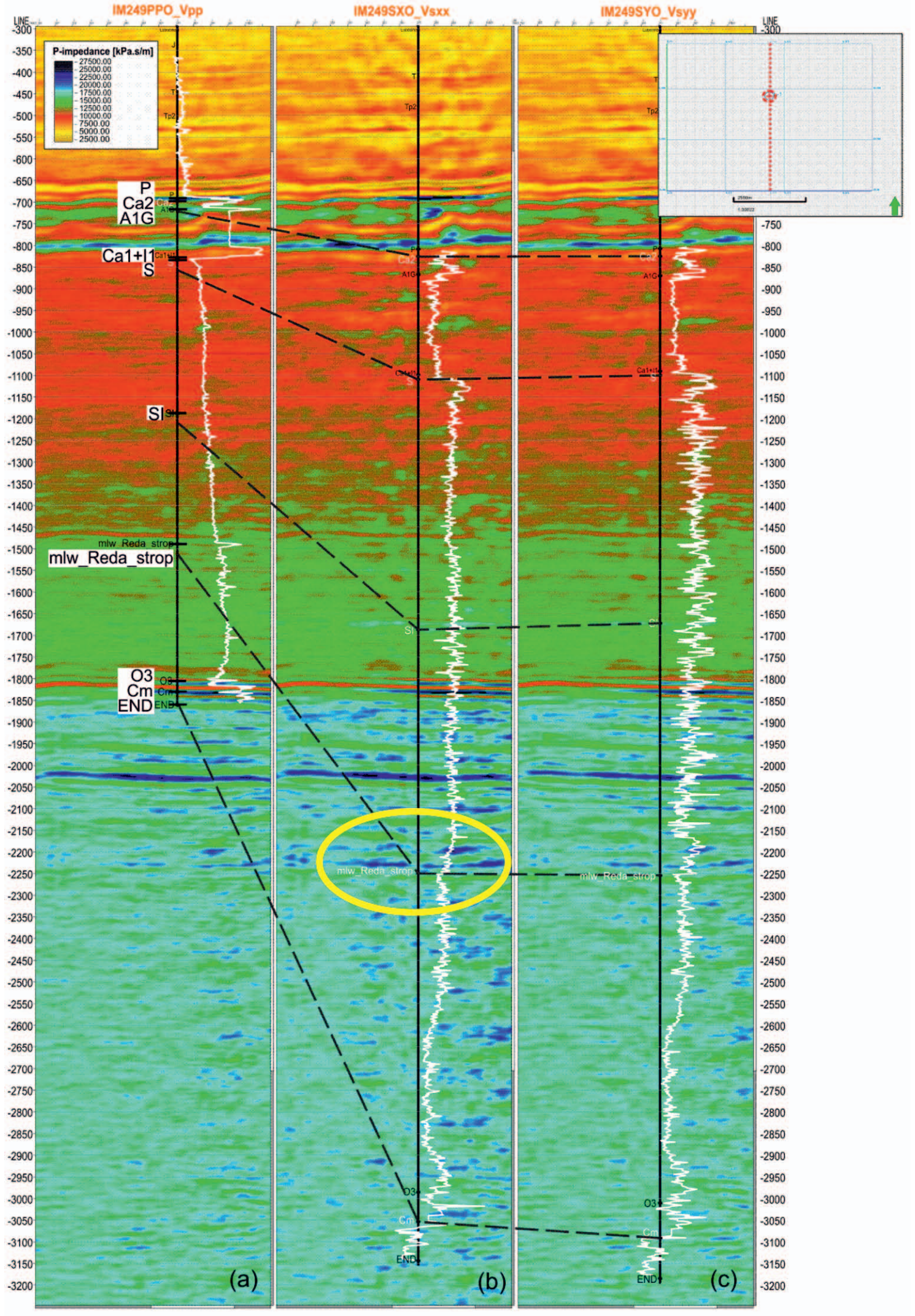

Rys. 24. Porównanie wyników inwersji sejsmicznej obliczonej na sekcji czasowej poddanej uprzednio różnym opcjom modyfikacji spektralnej: (a) uwzględnienie spektrum fal podłużnych (składowa pionowa - Z); (b) uwzględnienie spektrum fal poprzecznych (składowa transwersalna - SX); (c) uwzględnienie spektrum fal poprzecznych (składowa radialna - SY) 
Fala $S_{\text {_ }}$ poziom sylurski_interwal [1600-1950 ms]

SXO Vsx

Whe si249sxo Vsx (3)

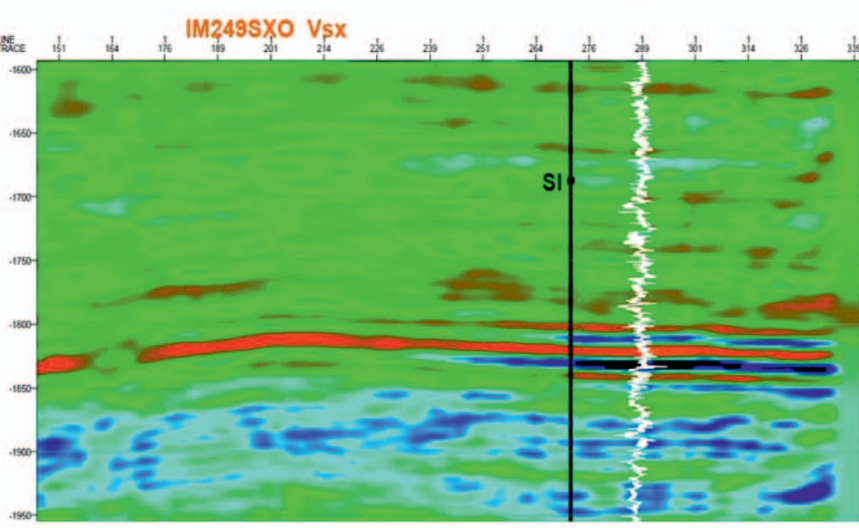

SXT Vsx
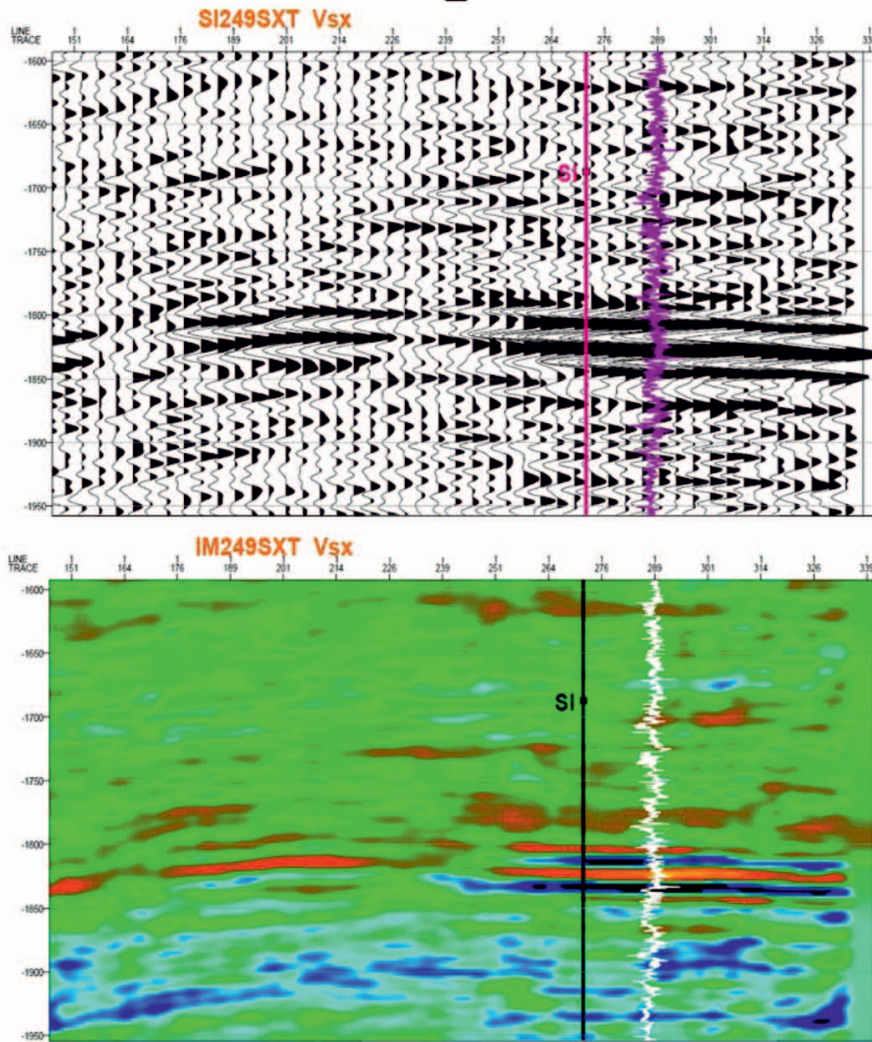

Fala $S_{\text {_ }}$ poziom sylurski_interwal [1600-1950 ms]
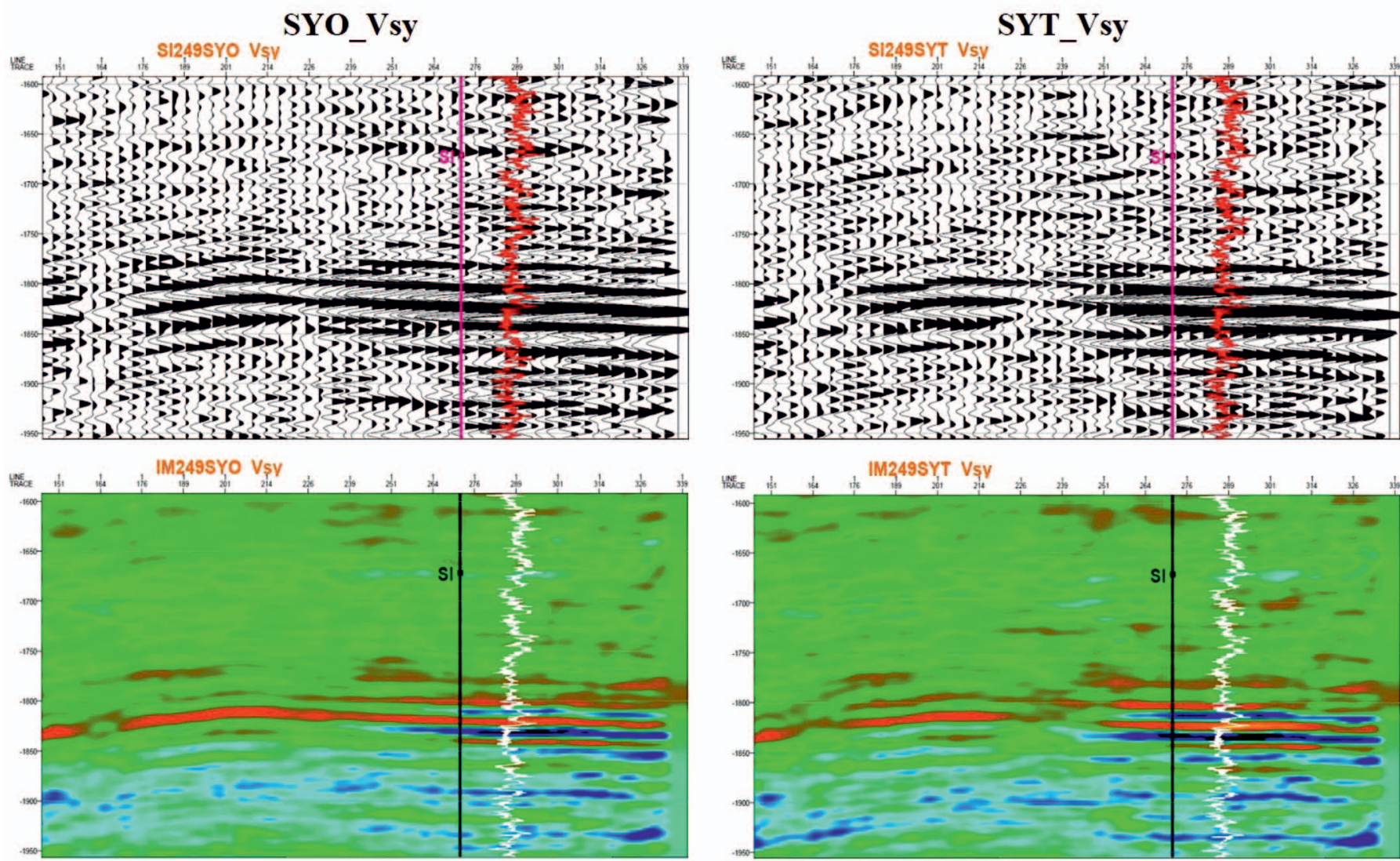

Rys. 25. Obraz pola sprężystego (opcja amplitudowa i impedancji) uzyskany przy zastosowaniu różnych operatorów modyfikacji spektralnej 


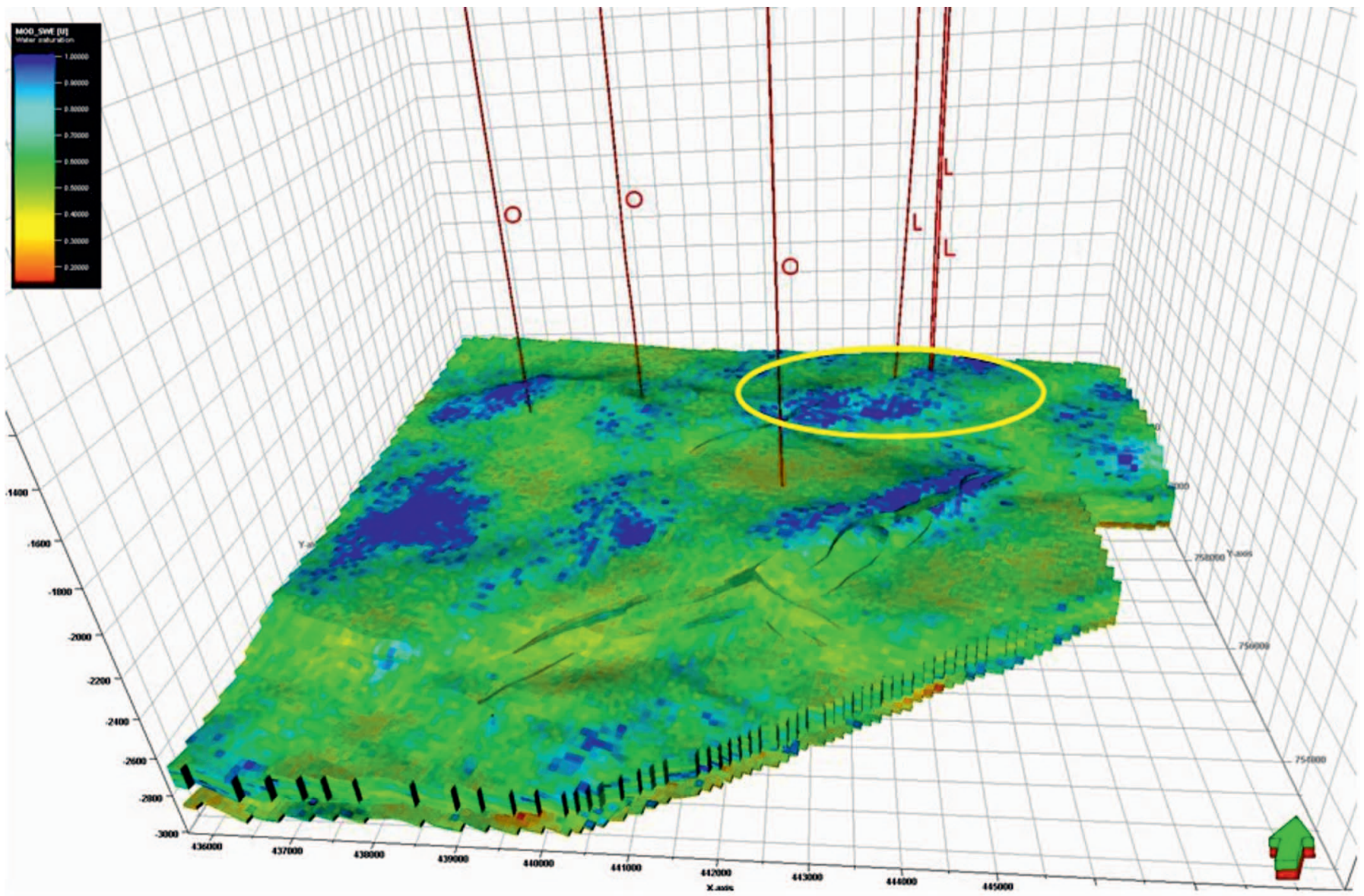

Rys. 26. Fragment mapy nasyceń wymodelowany dla wybranej warstwy formacji łupkowej z zaznaczoną jedną z anomalii parametru $S w$

\section{Podsumowanie}

Potrzeba poszukiwania rozwiązań nietypowych sytuacji zbiornikowych wyzwala wiele inicjatyw badawczych, których prostota metodyki i stosunkowo niewielki koszt realizacji zachęcają do szerszego testowania i zastosowania. Jednym z takich rozwiązań jest analiza właściwości pola sprężystego fali poprzecznej, dostępna w ramach opracowanych modułów programowych modyfikacji spektralnej i optymalizacji rozdzielczości danych sejsmicznych fal podłużnych, wykorzystywana do predykcji operatora modyfikacji spektralnej, uwzględniającego charakterystykę częstotliwościową pola fali poprzecz- nej. Poszerzeniem zaproponowanej koncepcji może być pełniejsze zastosowanie informacji o profilowaniach w otworze.

Proponowane rozwiązanie pozwala chociaż częściowo uzupełnić dotkliwy niekiedy brak wiedzy o parametrach propagacji fali poprzecznej, wynikający z faktycznie niewykorzystywanej w polskiej praktyce badań sejsmicznych metodyki sejsmiki wieloskładnikowej 3C (ang. multicomponent seismic 3C) - właściwie niezbędnej wszędzie tam, gdzie zjawisko anizotropii może mieć decydujący wpływ na efekty prospekcji i eksploatacji węglowodorów.

Prosimy cytować jako: Nafta-Gaz 2017, nr 11, s. 811-834, DOI: 10.18668/NG.2017.11.01

Artykuł nadesłano do Redakcji 21.02.2017 r. Zatwierdzono do druku 23.05.2017 r.

Autorka dziękuje p. dr Krystynie Żukowskiej za napisanie programów i wykonanie obliczeń oraz p. Irenie Irlik za perfekcyjną graficzną wizualizację wyników.

Prezentowane badania i uzyskane wyniki są efektem realizacji zadania wchodzącego w skład projektu BLUE GAS - Polski Gaz Łupkowy pt.: Badania sejsmiczne i ich zastosowanie dla detekcji stref występowania gazu z łupków. Dobór optymalnych parametrów akwizycji i przetwarzania w celu odwzorowania budowy strukturalnej oraz rozkładu parametrów petrofizycznych i geomechanicznych skat perspektywicznych (GASLUPSEJSM). Zad. 2. Poszukiwanie, rozpoznawanie - modelowanie i przetwarzanie danych sejsmicznych, w tym metodyka określania żądanej rozdzielczości sejsmicznego pola falowego w procesie lokalizacji, udostępniania i eksploatacji formacji łupkowych - praca INiG - PIB na zlecenie NCBiR; nr zlecenia 6110/SG, nr archiwalny: DK-4100-0601/07/13. 


\section{Literatura}

[1] Crampin S., Peacock S.: A review of the current understanding of seismic shear-wave splitting in the Earth's crust and common fallacies in interpretation. Wave Motion 2008, vol. 45, nr 6, s. 675-722, DOI: 10.1016/j.wavemoti.2008.01.003.

[2] Crampin S., Volti T., Stefánsson R.: A successfully stressforecast earthquake. Geophysical Journal International 1999 , vol. 138, nr 1, s. F1-F5, Bibcode: 1999GeoJI.138....1X, DOI: 10.1046/j.1365-246x.1999.00891.x.

[3] Hess H.H.: Seismic Anisotropy of the Uppermost Mantle under Oceans. Nature 1964, vol. 203 (4945), s. 629-631, Bibcode: 1964Natur.203..629H, DOI: 10.1038/203629a0.

[4] Jędrzejowska-Tyczkowska H.: Dobór optymalnej rozdzielczości sekcji sejsmicznej $w$ drodze analizy i modyfikacji charakterystyk spektralnych danych sejsmiki powierzchniowej i otworowej. Nafta-Gaz 2017, nr 8, DOI: 10.18668/NG.2017.08.01.

[5] Jędrzejowska-Tyczkowska H.: Niejawne aspekty procedur zwiększenia rozdzielczości i rozszerzenia zakresu częstotliwości sejsmicznego pola falowego. [W:] Rzeczpospolita tupkowa - Studium wiedzy o gazie tupkowym. Prace Naukowe INiG 2012, nr 183, s. 71-89.

[6] Jędrzejowska-Tyczkowska H.: Odtworzenie pożadanej rozdzielczości danych sejsmicznych $w$ aspekcie realizowanych zadań geologicznych. Prace Naukowe INiG 2012, nr 182, s. 57-63.

[7] Jędrzejowska-Tyczkowska H.: The Impact of Phase Characteristics on Seismic Data Resolution. Second EAGE/SBGf Workshop, Copacabana, Rio de Janeiro, Brazylia, 4-5.11.2014.

[8] Jędrzejowska-Tyczkowska H.: The influence of disturbances and noise of normal distribution on the correctness of geological interpretation of seismic sections with increased resolution. Nafta-Gaz 2015, nr 12, s. 59-71, DOI: 10.18668/ NG2015.12.01.

[9] Jędrzejowska-Tyczkowska H., Davis T.L.: Wanted and unwanted effects of surface seismic data resolution improvements. First Break 2012, vol. 30, nr 9, s. 75-82.

[10] Jędrzejowska-Tyczkowska H., Sowiżdżał K.: Importance of seismic data resolution on geological results of multidisciplinary geophysical research including $3 D$ geological modelling. International Conference „Engineering and Telecommunications Technology", Moskwa 2014, Publisher IEEE Computer Society, Los Alamitos, CA, USA, s. 116-117.

[11] Jędrzejowska-Zwinczak H.: Algorithm for computing kinematic and dynamic characteristics of the total field of head waves in a plane - parallel multilayer medium. Acta Geophysica Polonica 1974, vol. 22, nr 1, s. 43-63.

[12] Jędrzejowska-Zwinczak H.: Analiza widmowa fal refrakcyjnych podtuznych i przemiennych - zarejestrowanych na obszarze syneklizy perybattyckiej. Nafta 1971, nr 1, Biuletyn IN, nr 1, s. 3-4.

[13] Jędrzejowska-Zwinczak H.: Hodografy fal refrakcyjnych podtuznych i przemiennych w ośrodku o granicach płaskich-poziomych $i$ nachylonych. Nafta 1971, nr 1, Biuletyn IN, nr 1, s. $1-3$.
[14] Jędrzejowska-Zwinczak H.: O możliwości zastosowania fal niepodlużnych $w$ metodzie bezpośrednich poszukiwań. Nafta 1979 , nr 4, Biuletyn IGNiG, nr 1-2, s. 1-6.

[15] Jędrzejowska-Zwinczak H.: O wspótczynnikach ttumienia fal refrakcyjnych podtuzinych PPP i przemiennych PPS zarejestrowanych na obszarze syneklizy perybałtyckiej. Geofizyka i Geologia Naftowa 1971, nr 1-2, s. 7-12.

[16] Jędrzejowska-Zwinczak H.: Obliczanie intensywności podtużnych i przemiennych fal refrakcyjnych. Geofizyka i Geologia Naftowa 1970, nr 9-10, s. 275-282.

[17] Jędrzejowska-Zwinczak H.: Określenie stosunku prędkości propagacji fal podtuznych i poprzecznych $w$ strefie matych prędkości. Nafta 1970, nr 9, Biuletyn IN, nr 5, s. 19-20.

[18] Jędrzejowska-Zwinczak H.: Problematyka fal niepodtużnych w badaniach sejsmicznych. Prace IGNiG 1979, nr 27, s. 167.

[19] Jędrzejowska-Zwinczak H.: Zastosowanie funkcji korelacyjnych do badania zinterferowanego zapisu fal przemiennych. Nafta 1970, nr 11, Biuletyn IN, nr 6, s. 21-22.

[20] Jędrzejowska-Zwinczak H.: Zastosowanie modelowania matematycznego do analizy procesów propagacji fal sejsmicznych. Cz. I. Geofizyka i Geologia Naftowa 1973, nr 11-12, s. $361-364$.

[21] Jędrzejowska-Zwinczak H.: Zastosowanie modelowania matematycznego do analizy procesów propagacji fal sejsmicznych. Cz. II. Geofizyka i Geologia Naftowa 1974, nr 1-2, s. 25-32.

[22] Jędrzejowska-Zwinczak H.: Zastosowanie załamanych fal przemiennych $w$ sejsmicznych metodach poszukiwań do badania głębokości i charakteru zalegania podłoża krystalicznego. Geofizyka i Geologia Naftowa 1969, nr 10-11, s. 295-303.

[23] Jędrzejowska-Zwinczak H., Pustówka A.: Algorytm i program obliczania charakterystyk kinematycznych i dynamicznych calkowitego pola fal wielokrotnie odbitych $w n$-warstwowym ośrodku pochłaniajacym o granicach płasko-równolegtych. Biuletyn IGNiG 1976, nr 7-8, s. 25-32.

[24] La Barre E., Davis T., Benson R.: Finding the sweet spot. Exploration \& Production, Procceding of Colorado School of Mines, 19.03.2008.

[25] Sowiżdżał K., Stadtmüller M., Lis-Śledziona A., Kaczmarczyk W.: Analiza porównawcza formacji tupkowych $w$ wybranych strefach basenu battyckiego na podstawie interpretacji danych otworowych $i$ wyników modelowania geologicznego 3D. Nafta-Gaz 2016, nr 11, s. 891-900, DOI: 10.18668/ NG.2016.11.01.

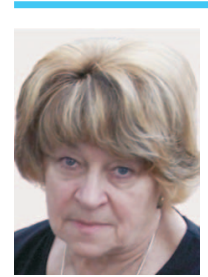

Prof. nzw. dr hab. inż. Halina JĘDRZEJOWSKATYCZKOWSKA

Instytut Nafty i Gazu - Państwowy Instytut Badawczy ul. Lubicz 25 A

31-503 Kraków

E-mail: tyczkowska@inig.pl 